\title{
Oral History of Charles R. Wright (1927-2017)
}

\section{Official Transcript}

\author{
Interviewed by Jefferson Pooley \\ June 10, July 19, July 27, 2016 \\ Communication Scholars Oral History Project \\ Annenberg School for Communication Library Archives (ASCLA) \\ University of Pennsylvania
}

The audio recordings are available on the ASCLA site.

The Annenberg School for Communication Library Archives (ASCLA), at the University of Pennsylvania, collects, describes, preserves, exhibits, and makes available to the University community, and scholarly publics more generally, materials pertinent to the interdisciplinary field of communication and its history.

CC BY-NC 4.0 


\author{
Oral History Project \\ Annenberg Library Archives \\ Annenberg School for Communication \\ University of Pennsylvania \\ Philadelphia, PA
}

\title{
CHARLES R. WRIGHT
}

\author{
interviewed by \\ JEFFERSON POOLEY
}

June 10, July 19, and July 27, 2016

Haverford, PA

Creative Commons CC BY-NC 4.0 


\section{BIOGRAPHY}

Charlie R. Wright (b. 1927) is a distinguished sociologist of mass communication, noted for his functionalist analysis of media as codified in the 1959 book Mass Communication. After graduate training in sociology at Columbia University in the 1950s, Wright taught at UCLA and, since 1969, at the Annenberg School for Communication at the University of Pennsylvania where he remains Professor Emeritus. Born in 1927 in Pennsauken, New Jersey, Dr. Wright grew up in a working-class family during the Great Depression. His father was unemployed on and off through most of the 1930s, until the economy picked up on the U.S. entry into World War II. After getting turned back as a 16-year-old, Charlie successfully enlisted in the Navy a year later, serving as an electronic technician. With the war over, he enrolled as an undergraduate (1946-1949) at Columbia with only a vague interest in public opinion and communication. A charismatic teacher, the sociologist William Casey, encouraged him to apply to Columbia's graduate program in sociology, whose affiliated Bureau of Applied Social Research was already celebrated for its work on mass communication. In the graduate program (1949-1954) Wright served as an assistant to Paul Lazarsfeld and Robert Merton, and began a lifelong collaboration and friendship with survey researcher Herbert Hyman. Wright took up a sociology post at UCLA in 1956, after a post-doctoral stint as a Columbia instructor. At UCLA he continued his work with Hyman, which over the decades spanned projects - and major monographs - on education $(1975,1979)$, program evaluation (1962), and international development (1967). Wright also wrote his groundbreaking Mass Communication: $A$ Sociological Perspective (1959) volume as a UCLA sociologist, along with a much-reprinted journal article (1960) making the case for a functionalist approach to communication. For decades, and across three editions (1975, 1986), 1959 book, Mass Communication, has stood as a leading primer for students and faculty, charting an approach to media that foregrounds the social. Especially in the discipline's early years, when psychological and medium-specific assumptions guided most research, Wright's book served as an influential and widely read plea to incorporate norms and roles, childhood socialization, and even social order into communication studies. Wright took a leave from UCLA in the late 1960s to serve as the National Science Foundation's program director (1967-1969) in sociology and social psychology, after which he accepted an offer to join the still-young Annenberg School. For over 30 years, and well after his formal retirement in 1996, Wright taught his signature course on the Sociology of Mass Communications to generations of Penn PhD students. That course and indeed Wright's career-long project to instill a sociological sensibility into communication research - had its roots in his mid-1950s teaching as a Columbia graduate student and instructor. In the intervening decades, Wright has left his mark on hundreds of colleagues and students, has devoted his long and distinguished career to bringing sociology to bear on the young discipline of communication. 


\section{ABSTRACT}

\section{Session One (June 10, 2016) - page 6}

Wright discusses his early childhood growing up in Pennsauken, New Jersey, in the Great Depression, his decision to enlist in the Navy in World War II (1944-1946), and his emerging aspiration to attend college. Wright describes his undergraduate education at Columbia University (1946-1950), including the special importance of the sociologist William Casey. Wright's graduate experience at Columbia as a sociology doctoral student (1950-1954/1956), including his administrative assistantships for Paul F. Lazarsfeld and Robert K. Merton in the early 1950s, is recounted. Wright discusses his encounter and early collaborations with the social psychologist Herbert $\mathrm{H}$. Hyman at Columbia in this same period. Wright describes the grant-funded project on the Encampment for Citizenship summer camp evaluation research in collaboration with Hyman, conducted in the early 1960s. Other topics include communication as a social process distinct from psychology, the publication history of Mass Communication: $A$ Sociological Perspective (1959), the place of communication in sociology and in journalism schools, the history of sociology at Columbia, efforts to establish quantitative research in journalism and in sociology at UCLA in the late 1950s and 1960s, his writing style, and his graduate teaching philosophy.

\section{Session Two (July 19, 2016) - page 27}

Wright recounts his family history, as well as his father's Depression-era and wartime employment history. He discusses his graduate training at Columbia (1950-1954/1956), including his 1951 master's thesis (a content analysis of magazine advertisements) and his 1954 doctoral dissertation project (a study of professional socialization in graduate student research training). The session includes more recollections of Columbia sociology figures, including Paul F. Lazarsfeld, Morris Rosenberg, Robert K. Merton, and Herbert H. Hyman. Wright describes his experience teaching, as a graduate student, in Columbia's Contemporary Civilization course, as well as a variety of undergraduate sociology courses (1952-1956). Wright's early years in UCLA's Sociology and Anthropology Department are covered, including his work on what became the 1959 book Mass Communication: A Sociological Perspective. That book's relationship to sociology, psychology, and Mertonian functionalism is discussed. Wright returns to the theme of his collaborations with Hyman, including a pair of re-analyses of survey data on Americans' participation in voluntary associations (1958 and 1971). Wright's early 1960s work on public leadership, and on access to commercial survey research, was also covered. The impact of Wright's 1963 visiting professorship in Santiago, Chile, sponsored by the Organization of American States, is recounted with a focus on his subsequent teaching style. 
Session Three (July 27, 2016) - page 50

The interview, after filling in gaps from Wright's Columbia period in the 1950s, focuses on his experience at UCLA in the 1960s, including his recollections of the sociologist Ralph Turner and journalism scholar Jack Lyle. Wright describes his two-year stint at the National Science Foundation (1967-1969), and his 1969 decision to move to the University of Pennsylvania's Annenberg School for Communication. He recounts his decades of teaching and research at Annenberg, including his recollections of George Gerbner, Larry Gross, Kathleen Hall Jamieson, Ray Birdwhistell, and Michael Delli-Carpini. Other topics addressed are his collaborations with Herbert Hyman on expert opinion in developing countries and on education in the U.S., a graduate training program at UCLA, his writing and teaching styles, and his relationship with his late wife Anne Marie Krefft Wright.

\section{RESTRICTIONS}

None

\section{FORMAT}

Interview recorded on a Tascam DR-680MKII Portable Multichannel Recorder. Three two-hour mp3 files.

\section{TRANSCRIPT}

Transcribed by Beatrice Field and Jefferson Pooley. Audited for accuracy and edited for clarity by Jefferson Pooley. Transcript reviewed and approved by Charles R. Wright and Jefferson Pooley. Transcript 72 pages.

\section{BIBLIOGRAPHY AND CITATION FORMS}

\section{Audio recording}

Bibliography: Wright, Charles R. Interview by Jefferson Pooley. Audio recording, June 10, July 19, July 27, 2016. Oral History Project, Annenberg Library Archives, Annenberg School for Communication, University of Pennsylvania. Footnote example: Charles R. Wright, interview by Jefferson Pooley, audio recording, June 10, July 19, July 27, 2016, Oral History Project, Annenberg Library Archives, Annenberg School for Communication, University of Pennsylvania, mp3 file 2 . 


\section{Transcript}

Bibliography: Wright, Charles R. Interview by Jefferson Pooley. Transcript of audio recording, June 10, July 19, July 27, 2016. Oral History Project, Annenberg Library Archives, Annenberg School for Communication, University of Pennsylvania. Footnote example: Charles R. Wright, interview by Jefferson Pooley, transcript of audio recording, June 10, July 19, July 27, 2016, Oral History Project, Annenberg Library Archives, Annenberg School for Communication, University of Pennsylvania, pp. 34-35. 


\section{Transcript of interview conducted June 10, 2016, with CHARLES R. WRIGHT}

Haverford, PA

Interviewed by Jefferson Pooley

POOLEY: OK, this is day one of an oral history interview of Charles R. Wright, conducted by Jefferson Pooley in Dr. Wright's home in Haverford, Pennsylvania. The interview is part of the Oral History Project of the Annenberg Library Archives of the Annenberg School for Communication at the University of Pennsylvania and the date is June 10, 2016. So, welcome to the interview, Charlie, and I wanted to start off talking about your biography and in particular your early childhood. Please tell me about your early childhood.

WRIGHT: My what?

POOLEY: Your early childhood.

WRIGHT: Oh, yeah. As time goes on, you remember less of some things and more of others. And so I'm going to tell you a few stories because I've taken from those stories something, some impressions, that have influenced my personal life and my professional life. First of all, I was born over in New Jersey, so I have all the New Jersey folklore [laughter] up in my head. I came from a working-class family of modest means but I was born during the beginning of the Depression, the great economic Depression of the 1930s and early 40s, so for a substantial part of that decade or so, my father was out of work. Lots of people were out of work. I was only a little boy then, at the beginning of it, but I could see the lines forming around the streets around plants like Campbell Soup in New Jersey in Camden, and RCA Victor, and they were hard-working men who were looking for any kind of income. They'd work for a day or work forever if you hired them - that would be fine. But that left a deep impression on me - not so much economic insecurity, though a little of that, but just despair that all these good men who wanted to work couldn't find work, and that continued during the 1930s till the year or two before the Second World War started. Then jobs begin to open up and did open up. Things economically improved. So anyhow, I come with that background and that memory of the frustration that working people have when the economy is flat, or when the economy is dipping - it's not even flat - it's crashing. So that's, that stuck with me. I went to public schools, and in those days you hardly saw a man teaching in public schools in the elementary level. It wasn't until I was in the sixth grade that I saw a man teaching anything. I don't remember much about him at all, so why do I bring him up? Well, he contacted my parents and said I wasn't going to go anywhere or any place in life, because I read too slow. Hello! And that upset them. And it just baffled me, because I knew I could read. I started, I learned to read before I went to school. My father taught me - I guess I was about five years old - and he started with the newspaper, 
and I got up on his lap and we'd read something, and he'd tell me what it was. I had a pretty good start, in fact, because I could read when I got to first grade. Now, incidentally, we didn't have kindergarten or pre-kindergarten in our public school system at that location, anyhow. So they skipped me one semester [5 MINUTES], and I jumped ahead. My father was proud, my mother was alarmed. He'll be in there with people older than he is, she said. And I was with people - and I've been comfortable with that all my life. It didn't bother me. Anyhow, to get back to the point. The sixth grade teacher tells my parents, He's not going to be anything in life, he can't read fast enough. And that stunned me. I enjoyed reading. I thought I read fast. I used to ponder that, what was the problem? And the only solution I could give to myself, whether it was right or wrong, was that I thought, I'd read a couple sentences and then I'd stop and think about them. That takes time [laughter]. That's the way I read for the rest of my life. And, in terms of my occupation, it was fine. It was better to read less and think more, than to read lots of pages quickly and only hit the highlights, because often the interesting things maybe weren't intended by the author but nevertheless you put them together as you stop and think about what this said here and not what it says back there and all that. So, that didn't bother me. Well, it bothered me, but I overcame it, for my purposes. I didn't overcome it if I really wanted to just read in a hurry, and dash on, but I didn't. That worked out OK. Secondly, we had excellent teachers back then, despite that one flaw, this poor man. I ... I didn't realize how truly excellent they were till years later when I got out my old yearbook from the high school like we all do, and for the first time paid attention to the credentials that they had. They had PhDs from Penn, master's degrees from Temple. They were a very good, very well-educated people, and they cared about their students. So that made an impression on me later in life. During the time, I was just as much a smart-alecky teenager as everybody else was. By the time I graduated, at the age of 17, I knew everything in the world - which was nothing, but that's the way it worked out [laughter]. So I came out of high school. I'd had enough schooling anyhow. I wasn't going to, I was going to out to work or something like a real man should. But we were in the middle of the Second World War, and that sense of patriotism drove me to volunteer rather than wait for the draft. We had a draft of young people at that time, most of whom were, I think - I never saw figures on it but - most of whom headed for the Army for the draft. But I volunteered, and volunteered for the Navy. I was not yet graduated. I was 16 [laughter]. And off I trotted to enlist in the Navy, and they said, Come back when you grow up, boy [laughter]. I was stunned again. But I waited a few more weeks, and I was 17, and three of us from the class went up to New York all independently - we didn't collude on it, we just happened to all go, and went to New York to volunteer. New York grabbed us up like in a minute. But, I must say, they were good about it. They said, Look, you've only got six week or so to you graduate, so what we'll do is sign you up now, but you're on inactive duty for the remaining [10 MINUTES] part of your schooling or semester, and then we'll call you up and send you to boot camp. They had that - that was the elementary training centers for the Navy. And they were as good as their word. They did that. So we all got our diplomas and went into the service. So that chapter of my life was over, except in my memory. It stayed there. But I thought, everybody played fair and square. That was good [inaudible]. When I was in school, in high school, and we only lived across the river in Camden, New Jersey, Merchantsville to be exact, used to come down. They ran ferry boats from Camden to docks in the Philadelphia shore. But that was a good place for us to go, we young fellows, to go and do some window shopping or go to theaters. We had 
theaters in Philadelphia then and they had Broadway-type plays, often before they went to Broadway. They used Philadelphia as a tryout center, you know. So you'd do that. What l'd like to do on Saturdays was catch the boat over to Philadelphia. They landed around the foot of Market, or maybe, perhaps Arch, or some other... I didn't know just where the dock came in. But I would head over to Market Street, and start to walk just to see what I could see. And those were good walks. I usually ended up at City Hall. That's about as far as I could get. But I saw shops that manufactured or sold, or both, men's clothing, hats, interesting things for a boy to see. And sometimes I got up as far as Franklin Institute, and that was a fun house. At that time, they had lots of machinery that you could work with in the museum and I thought, wow, maybe I'll be a scientist. Wow, you can do all these things! But I didn't, I was... After I was graduated, I went into the service. On one of my walks up, I got as far west as Drexel [University]. That was a long walk from the Delaware River up across the Schuylkill [River] to Drexel. And I didn't know anything much about it. I saw a sign that said, "Drexel University" - I don't know where it was. And I thought, wow. I wonder if I'd ever be able to get into a place like that? That was way above my head, I thought. So I had that memory. I went into the Navy. I had been pretty good at mathematics and I had a knack for interpreting schema of wiring or where pipes went or whatever, so the Navy put me through a long training process and I came out an electronic technician. At which I was not bad. And I made, finally made second class petty officer, second class. But somehow, almost like Pavlov's dogs, I got to associate the technical way of working with the hierarchical military system. And I didn't like the latter very much. I understood it was necessary to have a hierarchy. And you were going to go into danger perhaps. You just had to work that way. But when I came out, they said, "You know, well, stay in. Next thing you know you'll be first class, then chief. And you can really waddle around and do things." And I said, no, I want out. And I got out. While I was in the service, I observed how, how far you could not go [15 MINUTES] if you didn't have more schooling, let's put it that way. So I began to change my attitude about additional schooling, but I also changed my attitude about the areas that I would like to do that in. I wanted nothing more to do with engineering and technical stuff, because I think of that psychological melding of the two in my own brain. So ... and I had read a book while I was in the service by a man - at that time, he was just a man to me - named Jacques Barzun, a famous historian at Columbia [University]. And he'd written a book called Teacher in America, and it really grabbed me. It was very interesting. I thought, that's a place I'd like to go. But I'd never get in there, my gosh. Columbia was like on a Mount Olympus up there. But I knew I had to go to college, or junior college, or anything to get more schooling, unless I wanted to be taking orders all of my life. And I'd had enough order-taking in the military. I didn't want any job where people would tell me what I had to do. I thought, what kind of jobs might that be? Now, my fantasy brain said, right now [inaudible], go down in the Caribbean and sit on the beach and have a good time. My rational side said, I don't think you're going to do that, but I'm going to try. But it wouldn't hurt to have a little college education too. So I picked out three schools that offered what I thought I'd like. Columbia was one of them, University of Chicago was the second one, then I thought, I better have an ace in the hole. I'll apply to Rutgers [University]. Rutgers could never turn down a citizen of the state just coming out of the military and all that. So I wrote off to all three places, and I got accepted in all three places [laughter], and I had to make a choice. And I picked Columbia partly because of the influence of Barzun's writing, partly because of the glamour and excitement that New York City 
offered compared - well, Chicago wouldn't have been a bad choice, but New York was it. So up I go, trot, trot, trot, to New York. I'm off to great start, I get on the wrong subway, and I ended up not at Columbia on Morningside Heights, but on 116th Street down in Harlem, which was on a plateau a little bit lower down than Morningside Heights. Here I am, I'm a terror now, I've been in the service, I know my way around, blah, blah. But I didn't. Where am I? I'm sitting here on this corner of 116th Street, and I couldn't see what the other street was. Well, I must say, the people were marvelous. No problem. They said, "Oh, you've gotten on the wrong subway, kid. Go here, go do that. You gotta be up there"... So, I found my way, but I was left with a nice impression of the citizens of New York. They were like people in Philadelphia were you needed help, they'd give you some. Not like it is nowadays. The climate was very different. And if you were a service man, or an ex-service man, nothing was too good for you. They'd just welcome you. So off I went, and started my schooling. I took liberal arts, a little of everything, but sampling some things. I thought, well, I'm going to be this hotshot, cigar-smoking author of racy novels. I better see if I can write [laughter]. So I took a summer course - I don't remember the instructor's name now - where we did some writing and turned them into him. And I can remember to this day him standing up in front of the classroom [20 MINUTES] and giving back the papers with the comments, until he came to mine, and he said, "Go get some experience" [laughter]. That's all he said. And I figured, OK, he was being kind and telling me that I hadn't grown up yet, despite my background. So I put that aside and went to take more other courses. Took Barzun's courses, realized for the first time that I didn't know enough to gain what I should've gained from his lectures. He was up here and I was still down there. Well, that was a good lesson to learn. And I read stuff I'd never read, and ran across names of people that I've never heard of in my life and put that all in my - if not in my pocket, at least someplace, in my sock maybe. I kept those memories.

POOLEY: Can you mention some of those?

WRIGHT: Oh, excuse me.

POOLEY: Can you expand on some of those names that you encountered?

WRIGHT: Oh, I'm missing you.

POOLEY: Can you expand on those names, those figures, that you encountered when you were reading about Barzun, people that were kind of influential to you at the time?

WRIGHT: Well, the reason I was reading Barzun. Now, I'll take that back. You're right, I just picked it off the shelf and read it. But, you want me to, do what? Tell you what?

POOLEY: Were there other memorable figures or classes or teachers that you encountered at Columbia?

WRIGHT: Oh, at Columbia? Yes. The most memorable one is one that, no offense now, you've probably never heard of. Why have you never heard of him? He never published a word. He did 
all of his teaching orally, and refused to publish anything - literally, refused it - with the saying that, he would, it would, by the time it got published it wouldn't reflect his latest thoughts [laughter]. l'd put it that way. But he was a spellbinding lecturer, and his room was always packed. Almost everybody who went there took his course. It became known as... His name was William Casey. His course became known as Casey-ology, rather than sociology, and it was, it was exciting. Now I'm going to digress a minute. Years later, when I was out here on the East Coast again, I found a book. He didn't write it, but two of his former students tried to put together his lecture ideas and notes, and it helped a bit, but it wasn't... It didn't carry quite the excitement as his delivery did of that. But I read him and it was OK. Then one of the editors on the first, no the third edition of my paperback book on the sociology of communication, one of my editors at Random House was Prof. Charles Page, and he had been a student at Columbia, generations before, maybe, but he'd been there. He had come to Columbia because Casey had moved to Columbia from, I think, the University of Illinois. And Page was so captivated by his class and so forth that he followed him to Columbia and got his graduate work done there. And he wrote a book years later when he retired called 50 Years in the Sociological Enterprise: $A$ Lucky Journey, in which he... It's his memoirs, basically... And he says in there he wouldn't have been in sociology if it hadn't been for Casey and his teaching and his style of teaching and his concern about students and so forth. [25 MINUTES] And Page says when he, Page, got his first job - or a job, I take back the first part - he tried to, well, imitate's the wrong word. But he tried to follow the style of Casey, and he said it didn't work. It wasn't the same person as that. And the same thing's true with me. I didn't teach the same way that Casey did. It took me decades to get my own style, which I did. I was really teaching with, from my strong hand by the time I retired, officially retired back in 96 . It got better when I was just doing that one course at Annenberg. I had a different style. It was good. Anyhow, [inaudible]. So that was a person. The second person, I don't know his name to this day, I didn't even remember it. He gave... I took two courses with him, "Introduction to Economics," and then "Intermediate Economics" or something like that. It was the next step that you took. Because again I was exploring, would this be an area that l'd like to spend my life doing things in? They were the most boring courses I ever took in any place, and I'm, to this day I'm indebted to that instructor, that didn't jazz it up or anything. He just gave it the way it was, and I thought, I don't want to play with supply and demand curves in this or that. Where were the people in here? I couldn't find them. So I ... That helped me not to go into a field, or I would've been uncomfortable or unhappy even, at the time. So, yes, let's call that nameless influencer number one [laughter]. Casey was a positive influencer. There were others that I had that influenced me in different ways. I took Fred Keller's psychology class. So I think, psychology, I'd be interested in that. It's about people, yeah... We ran rats through the cages emulating... What was the name of the famous psychologist who did the rats? Anyhow, it was an interesting course, and I almost went into it, but I thought no, not quite right. The course involves the laboratory and that was good and I learned about laboratory work. We worked with partners. I had a classmate as a partner. And we, we met eye to eye pretty much. He couldn't do mathematics very well, poor guy. I could do mathematics with my left hand, so that was no problem. So I said, well, how are we gonna work this out? I said, I don't really want to handle those rats. He says, oh I don't mind that. OK, you handle the rats. So he'd set up the experiment. I'd take the numbers down and between the two of us, we made a success of it for us, yeah. And I thought, well, maybe that's 
the field I'll end up in, psychology. I talked with Fred Keller. He said, well, you really should take a course in physics, and one in this and one in that. And I thought, it's going to be a long time before I'll see anything except rats. I don't know if I want to do this or not. I'll think about it. I went to see Bill Casey. He said, what are you really interested in boy? And I said, well, I'm sort of curious about public opinion and the mass media, and how one influences the other, so I think I'll go on to graduate work in some school that has that kind of courses. And he said, well, that's fine. [30 MINUTES] He said, all you gotta do is go down the street one block. I said, what do you mean? Well now, I have to sidetrack. Columbia at that time was very distinct. Columbia College was a unit in the University, and very few graduate teachers taught in the College. So l'd never been exposed to this literal crew of fascinating, intelligent, hard-working sociologists in the Graduate School. It wasn't in the College. So he says, you don't have to go, just go down the street. He says, we have a couple of the nation's leading researchers in public opinion and communication. He says, just go down and talk with them. And he mentioned a couple names. Paul Lazarsfeld, Robert Merton. I said, OK, thanks, I'll go down and see what they do. And I went down. I don't remember to this day who I ended up talking to, but I got kind of a feel and an outline for the kind of work that was going on in the graduate department. I said, yeah, I've found my place. This is it. So I went in. Never regretted anything in the College that had been different, because I learned from the differences and I learned, and was prevented from making mistakes, that could have affected my whole life. So I went there to the College... To the graduate work. You don't want to hear about that now, you want to go, do you? We're going too fast for you.

POOLEY: No, I do have a question though. Was it Bill Casey who convinced you that... Was it Bill Casey who convinced you to major in sociology and did you end up making that your formal major?

WRIGHT: No, I liked Casey's courses. They were terrific. And I learned a couple things from them, not substantive but rather things about dealing with students again. I was always worrying about that. Casey gave a final examination that would have buried anybody. How in the world you could take that examination in the two hours they gave to you? So, a number of us, independently, just couldn't finish that exam. You really had to take it home and work on it. $\mathrm{He}^{\prime} \mathrm{d}$ given us all the questions in advance, but you never knew which ones would be on the exam, so you were reading like a maniac to catch up. I said, I'm sorry, I couldn't finish. He says, that's all right. You are going to finish, aren't you, young man? Ahh, yeah, yeah, I'm going to finish. He says, well, in that case, I'll give you an IOU. Here's your grade, and he wrote the grade on there. And he said, live with it. And he said, I'll see you later when you finish your paper [laughter]. And I was... I'm graduating from college. He was right. It took me two years, but I finished the doggone paper. I already was in graduate school. I took it in. He said, I knew you'd come through for me, old boy. [Inaudible] OK.

POOLEY: Do you remember what the paper was on?

WRIGHT: No, I don't know what it was. It was... in response to one of his many questions about big institutions like financing in London or banks in London or... [Inaudible]. But I learned to be a 
little patient with my own students if I thought they were going to come through. If somebody was just dogging it, yeah that was it, they were gone. But that, that became an important part of my outlook. If they are good and they're smart, and they just need a little more time - little more [inaudible] - it was OK. And he said, I'll tell you, he says, never in my whatever years I've been teaching at Columbia has anybody reneged on their promise. I thought that was astounding, [35 MINUTES] because they were doing other things, going to med school or law school or whatever. That was the hold he had on you. You couldn't disappoint that old man and look yourself in the face in the morning and shave. Yeah, I finished it.

POOLEY: And so you told him that you were interested in public opinion and communication. Did you have any coursework as a Columbia undergrad on communication, in the sociology program or anywhere else?

WRIGHT: No, no.

POOLEY: How did you develop this interest?

WRIGHT: We didn't have a major in communication. I took sociology and the two just melded later and so on. No... when I went to the graduate school part, I had a number of courses that were relevant to communication. They weren't called communication, though, they were just... Took Daniel Lerner's course, for example, in Psych War, he called it, with psychological warfare in the Second World War. That was relevant. Took all of Lazarsfeld's courses on political behavior and communication. That was relevant. We're getting sort of ahead of the story, but the fact of the matter is, Casey was right. We had down the hallway exactly the figures who emerged later as important contributors to communication. But, then, they were also working in other areas of sociology. Merton did studies on a housing project, and he did studies on medical education and the socialization of the students into medical practice. Lazarsfeld did stuff on consumer behavior, personal choice. So they had other, other fish to fry, but they did make major contributions to communications. If I had known that I was, was going to go into the area - and I didn't know it, and I did really go completely in, that's another story - but had I known that, I don't think there was anything like the Annenberg School existing at that time. You had journalism departments, but not schools of communication. They had schools of journalism, yes, but there's a big difference, and it's an important difference and l'd like to talk about that to you. But I don't want to get ahead of the story or out of whack. Well, you could always fit in chronologically if you wanted. How can I put this without sounding like I'm criticizing, and I'm not criticizing anybody. There are different approaches to the study of communications, and I think - but don't quote me on this - but I think the most common, at that time at least, would be you'd have a course on newspapers, or you'd have a section or chapter on newspapers, radio, television, other things. Depends how far you want to go. Telegraphs, why not? They're very good and they're very important, and they are useful to students who take them. I didn't want to do that. It may sound like verbiage, but it's not. I was beginning to view communication as a social process, and the machinery or tools were part of the process, but they weren't the whole thing. And you approach it differently if you take my point of view, and, although maybe under pressure occasionally I would have a look at the 
newspapers or TV, what it's like, that's all right. [40 MINUTES] But I'd be approaching them with an eye to their social side in the production and in the distribution of information or opinions or whatever it is you've got. That was well-received when I first did it. By the time I got to my third edition, we changed publishers, and I had a little tug-of-war with the editor of the third version, who wanted me - and, sometimes, I think I should have listened to him, who had done some kind of a market survey, and he said, the readers want to read about whatever it was, this, that, the other thing. I said, I don't want to write about this, that, or the other thing. I've got my own point of view, and I want to introduce that to the readers. I wrote that book mostly... The first edition was when I was out in California. By the third edition, I was here in Pennsylvania, I think, and I wrote that one. If I had listened to that editor - well-meaning, but he was stubborn, and I fought with him - if I had listened to him, I would've had a moneymaking sale, because that's what they did. They'd go out, find out what the kids in this college or that, they would want, and you put a book together like that, and you sell a lot of copies, and you go to Bermuda and you smoke your cigar and you lead the life. I don't want to do that. So, but people who did buy it liked that very much. And the approach that was there, which does not exclude the other thing. It's just in addition to it. I came to Penn - this is gonna sound very fuzzy minded, perhaps - but I left a good job in California, the Garden of Eden and paradise, 20 minutes to the beach. I left it all behind, because I thought l'd get students at Penn who would be interested in the kind of things I was selling or teaching. And I don't regret that, except on a cold February or March day. Then I regret it [laughter]. But, otherwise, intellectually I don't regret it. I did get more students who were interested in that - not scads, but enough to make it worthwhile. My mission that I put on when I came to Annenberg was that I hoped to suggest to graduate students, PhD particular students, how there are different approaches to understanding a phenomenon like mass communication. They were mostly biased towards a psychological approach. It just rang in that, everybody's mind, you can understand that so-and-so is whatever, paranoid or whatever they're going to do. I wanted them to think about the world surrounding that person, and how economic and the normative systems - families, structures - were important in shaping how he or she got their news, got their information and the like. It sounds simple, but believe me I was working hard at it for 60 some years. But, like Casey, I didn't push it prematurely into print. I had, I'd drop in a hint here or there, and sometimes it grew and sometimes it didn't grow. But at least I gave them a chance to not just think about the individual and his or her psyche and so forth - and that's why they got along or that's why they turned to dope or that's why they did this or that there's pressure going on them from peer groups, from reference groups, from the economy, from the opportunity structure that is not there when they go to look for work, [45 MINUTES] and the like. Again, further out of context, I'Il tell you a story from when I was director of programs, research programs in sociology and social psych - that's how I got my two exposures, communication came later - l'm sitting in my office down in Washington, and they've got a lovely barrier system, person to get, would have to go to the head secretary of the unit, and then she let them pass to the individual secretary for the program directors. Then you get to see them [inaudible]. Or you wouldn't get to see them if they didn't get through the barrier system. It worked out pretty well. But one day I'm sitting there and, it was around lunchtime, and a man appears at my door. The secretary hadn't buzzed me. And he says, are you the director of the program? And I said, yeah, grants - grants program is what they were. 
He said, oh great, I've been looking for you. I think, uh oh, is this some rejected candidate who's going to come out and pull the gun out or something? No, he was a pretty calm fellow. He comes and sits down and says, l've been working on something. He says, this idea came to me when I was on KP in the Army. Oops! What? What idea came to you? And he says, and I have it all here. I've got the secret to the cosmos and the secret to human behavior and the third area. I don't know what it was. Oh, yeah, that's interesting. And he says, well, I've gotten this far. I'll tell you about it. Starts to tell me about it. And I'm thinking, where is that secretary? Is there for buzzer here? He says, so what I want now, he says, I've got to bring all those great ideas all together, so give me some money [laughter]. I said, now, what am I going to do? I don't want to hurt this fellow's feelings and set him off into a rage. Well, I listened, and I'd say, well, that's very interesting, yes, that's interesting. Unfortunately, I don't have the authority to just give out money. I have to take all requests to a committee. I'm playing the bureaucracy game with the guy. So, l'll have to run your ideas through a committee first - and I'm taking this paper he's got there. And all of a sudden, he grabs the paper back, he says, you're not going to tell anybody my ideas, are you? And I said, I have to. No you don't. I'm not going to stand for that. I'm not going to deal with you. Out the door he goes [laughter]. Thank God for the bureaucracy, and he was gone. After a while, I said, Mary, why did you let that guy into the office? He's discovered the universe and the human body and all else, and she said, oh, I didn't see him, he seemed like a nice man. That was my story from there... It wasn't her fault, she was a perfectly good secretary. He slipped by somehow.

POOLEY: And just to clarify, this was the NSF?

WRIGHT: Yeah, but don't quote that please. I don't want to get them in trouble. They were very fair to everybody. If he had written that down and handed it to me to go, I'd have taken it to the committee. I never saw any bias. That was a good two-year experience for me. I went in having been fed the stereotypes that people had in the newspapers about how they're wasting the taxpayers money and this and that - pointy-headed bureaucrats - baloney. Those are hard-working, smart, well-schooled people doing a job. They didn't hand out grants to their friends as a favor, or... [50 MINUTES] And they didn't, they weren't biased against anything. The question was, can it be done and can this applicant do it? Now. The first part, you can have discussions, even debates whether this problem could ever be solved with that technique that they were going into. And we did talk about it. Sometimes, I'd be given ideas to go back to the applicant with, and say why don't you resubmit and make sure to have, whatever, a control the next time, or something like that. That worked all right. And sometimes they'd say, oh, Joe X, he hasn't finished the project in 30 years or something. OK. But they were fair about it. They weren't anti-qualitative. We had qualitative research. Didn't get many applications. I think, but I'm not sure, that the person's record played a great deal of influence on open-ended qualitative thing - was this someone you really could bet on if they're going to do a good job. Whereas an experiment or something, you can see how it's going to, how it's laid out. But they weren't against qualitative work, or pro-quantitative work. It depended on the problem. It was good experience for me and I came away very impressed. Yeah, anyhow, but to get back, where were we [inaudible]? 
POOLEY: Well, can you take us back to 1949, when you're thinking of a graduate program in sociology at Columbia? Can you take us to that moment? What was going on, how did you get admitted to the graduate program, and what are your impressions of it?

WRIGHT: OK. I got admitted like anyone else would. I wrote an application and they accepted me. That was fine. My experience in the program couldn't have, could not have been better. It was a wonderful educational experience, but it also was a wonderful, never articulated learning experience about research, teaching, people, all together. There was at that time ... Well, back stop, sociology didn't come to Columbia until the early part of the twentieth century. It didn't come to the U.S. until the early part of the twentieth century. There had been a chairman now I don't remember the exact dates anymore - but, in the very beginning, Franklin Giddings his name was. And he, I think, first had a chair in economics. I'm not sure about that but like that. And then, as the request for sociological training began to grow, the department added people and it grew. But at one time, in the very beginning, the president of Columbia had seriously entertained the idea of throwing it out [inaudible]. There was a common faculty economists, that one sociologist and some others - and then there was the bigger faculty of the Graduate Faculty of Columbia. Somebody convinced the president of the university to call a faculty meeting of the big faculty to vote on whether to get rid of sociology. And they voted no, they would keep sociology. So, that set the stage for future growth if possible. It could've been just dumped. There were a number of people in charge, [55 MINUTES] and I don't know them all [inaudible]. But, one early one at least was Robert Maclver, who was a, technically a political scientist, I would say, but a very broad-ranging Scottish-trained scholar. And then there were some others, I don't know who they were. What was going on over the country, I think, was similar in big universities, that sociology started out as either an appendage to economics or, basically, a social philosophy department. It wasn't until World War II that the empirical side of the field got strengthened and grew and eventually took over. That was partly because of the research that they were asked to do during World War II, like on morale of the troops and things like that. And partly because of the background and nature of some of the recruits into sociology like Lazarsfeld and Merton and others ... So it wasn't dying. It was growing, but you had a tension that continues today in many universities: the quantitative versus the qualitative. There's no versus. They could both work. They do different things, in my opinion. I'm just giving my opinion now. You get very rich material from qualitative research, and some people are very good intuitively at putting it together and making an interesting and fairly accurate story. A shortcoming, because it was never intended to do this, a shortcoming of some qualitative research is, you come out never knowing how common or how peculiar the cases that you looked at were. Are you dealing with just a fringe, or is this a majority feeling and so on? As soon as you take that step to want to know how many and what kind and where are they, you're going quantitative. But that's not hostile to the original thing. They got, made a good narrative out of it. So I saw that going on - well, I didn't see it at the time. Later, I looked back, I could see that was happening, and is continuing as I said. And here I'm on, next step I'm on so much shakier ground, but I think I see the same pattern going on in communication between the 1930 s or 40 s and now. It's moved more and more... I have no idea what this big data thing's going to turn out to be and I'm too old to start learning [inaudible]. You see the movement going on. Well, in journalism that was actually a tension between the old-style journalists and 
professors of journalism - we called them the eyeshade group - and the young, quantitatively oriented people like Steve Chaffee and others. I was in California at a time when a fairly large number of those young people were starting a, I don't know if they started a division in the society, anyhow, they were forming a unity, Jack Lyle was in it, Steve Chaffee was in on it. A few others. And they, I think they called themselves the quantitative group at that time. I'm not sure of that, but I think they did. I haven't kept up with them, Steve Chaffee's dead, Jack vanished - I don't know where he went to. But, again I'm getting off track but, at that time that would've been back in the 19, either the late 50s or the 60s, Jack Lyle from, [60 MINUTES] who was in the journalism department at UCLA, a man named Walter Wilcox I think it was, myself, somebody from psych, I forget who it was, anyhow, we all formed a group to help to steamroll the - what do I call it? - Journalism Department is what it was. To really get it on a sound footing, to get PhD's and things like that. I don't think they ever got it through. Now, not the same group, but some of the same group of people and myself again, looked around and we said, in order to train graduate students in doing research, we really need to have a laboratory or institute or some administrative body that will help us to get going. So Jack and I and the others we kept knocking ideas around, and we finally worked out the proposal - very modest. Which we took to the whoever was in charge of that at UCLA, the whole package. I forgot now whether we had, wasn't a provost, but they had some title. Including a budget. And we had figured out that to get established, hire a secretary so she could do some of the work, little equipment, whatever, we needed a startup grant. You know how much we asked for? Take a guess?

POOLEY: Five thousand.

\section{WRIGHT: How much?}

POOLEY: Five thousand.

WRIGHT: You're not far off. It was more than that. It was about, but it wasn't anything like the figures today. We thought we could do the whole thing for, tops, 30 grand, maybe. No, no... They' $d$ already budgeted and started and had operating a social science research unit up at Berkeley, Berkeley campus. I don't want to sound like a kid saying, you like me better, I like you better than she likes me. No, it wasn't that way. But Berkeley was a bit ahead of us. Many of the state people, state legislators, had gone to Berkeley, they liked it. And it's good, a good school. They had some terrific faculty. For a while, the research unit that they did set up was run by... I'm sorry, I'm losing names now. It'll come back to me anyhow. He was a good man, and he did well. We didn't ask for a hundred thousand or a million or something. Thirtythousand bucks. Didn't get it. And, as I say, communication was involved, or journalism, the department, was involved in that, trying to get that center set up, and also trying to get a doctoral program going. Very, very strange.

POOLEY: Charlie? Can we go back to 1949 in 1950 and the Bureau and the Department of Sociology? 
WRIGHT: And what? Oh, the department?

POOLEY: The department, and the Bureau, and the interaction between the two. I think you were the administrative assistant for a couple of years there in the department. The recollections you have of the Bureau and the department, together, one another.

WRIGHT: I'm not sure my view is right. I was looking to it, from the junior fellow trying to get ahead. Well, you know the history of the Bureau, and how it started out in Newark and splintered over in ... Lazarsfeld was mainly interested in, I think, in establishing an advanced research methods program type thing, and that was separate from the Bureau. [65 MINUTES] The Bureau was not part of the department, but it was affiliated in some ways. The directors were professors in sociology. There as an exception or two, but mainly it was that. I don't remember them all now. You had Edmund Brunner from rural sociology, Teachers College. And he was a big player in it. You had .. well, Lazarsfeld was director for a number of years, Merton took over for a number of years. Most of the big research that the Bureau did was with the principal investigator who was a prof there too. The Bureau provided the bread and butter for a heck of a lot of us graduate students. I only worked part-time at it, and had some role, but I wouldn't say ... There was some students who started at the Bureau and never left, and there was some like myself who dipped in a little bit and dipped out. If the profs got a big project, they usually had it administered through the Bureau, which had its own hierarchy of people in it and the like. I don't where, where to take the ... I had a little, worked a little bit on some projects that never, maybe later they came true. But I just did scut work like coding and whatever, carry papers around, do interviewing. The only big project that we got involved in was a project on the Encampment for Citizenship. That was a biggie. The board of directors, I guess, of the Ethical Culture Society managed a summer institute that they would increase young people's willingness and ability to be active democratic citizens, small " $d$," not political. And they came to the Bureau, because somebody recommended the Bureau as an independent agency that would help them. And it shuffled around and landed finally down in, on Herb's doorstep. And he recruited me right away to be his number one person on there. What can I tell you? It started out as.. well, I have to backtrack. The board for the American Ethical Culture Society that sponsored the whole thing had been sponsoring it for about nine years, they were coming on their tenth year, and they were curious about several things. One, did it work at all in getting the young people the willingness and the ability to do things, democratic? And, two, what worked and what didn't work? And, three, they were looking to the future, should they expand this thing by making five or six encampments, or more, or whatever they wanted to do? They didn't want to dump their money down a hole, that was not their purpose. They wanted a successful program, but they, and, if all they wanted was the feeling of success, [70 MINUTES] they had letters from alumni saying, oh, you changed my life, what a wonderful thing this summer was. Which was sincere. But, again, coming back to our differences, you never knew, was this just a flaky example of somebody who did benefit all by themselves, or was it a majority or whatever? So, they wanted to evaluate it and that's where Herb and I came in. Herb was especially interested in figuring some method for determining what worked and what didn't worked, and how much didn't. And I was interested in that to. It was clear that the project was going to take a fair amount of leg work. That was the qualitative part of it, and I did 
that [laughter]. And it was going to take a fair amount of paperwork. Computers were not so advanced as they are now - put it that way. So we did a lot of work ourselves that machines could do now, I guess. And we got interested in it. Now, how did we do it, so to speak? First of all, Herb and I agreed, we really had to pin down the people who were running the programs and see what they were trying to do. It was all there in black-and-white, but there were these vague terms - make better citizens, or whatever? Come on? What are you talking about? So I would say, we spent at least the first two months just talking to these people. Both Herb and I would go. We talked to them. And we began to get a feeling and then to get more than a feeling, to get some precision on the kind of changes they were hoping to make, or the kind of use they were hoping to reinforce if not change them [inaudible]. And the pie-in-the-sky stuff that, you know, whatever... And we worked that out and then we went back to them. Now a couple months have gone already. We go back to them and said, this is, is this what you're trying to do? And they say, yeah, yeah that's what we're trying to do. So then we went on from there to develop our design, our questionnaire and the like, knowing that we weren't just fiddling with something that was just pie-in-the-sky. It was concrete. And that was hard work, hard intellectual work, trying to sort these high-minded but vague ideas and concepts into something that you could measure and see whether it had grown or not or even regressed. If you wanted to think about it as regression, whatever it was. But we didn't leave it at that. Things happen that the sponsors and doers and programs don't expect, and some of the things could be counter to their intentions. So, we did, Herb and I did a pretty good job, I think, of searching the literature for any, other studies of evaluations of a general type that we were interested in. And we could see what they found and the like. The nearest thing that we found was a study done of a, save me, oh God, I'm sorry I can't remember the name of the organization now. It's well-known, it was Quaker, Quakers had it.

POOLEY: Friends Service Committee?

\section{WRIGHT: Beg your pardon?}

\section{POOLEY: The Friends Service Committee?}

WRIGHT: I think it was, but, look, you're going back decades in my brain here. And the study had been done by a good social scientist, Henry Riecken. [75 MINUTES] And we wrote to Hank, and he said, we wanted to take some questions, not the whole thing, but some questions that we thought were relevant in our case. And we told him the study we were doing, and he was quite cooperative. So that worked all right. We didn't find any other studies that were similar enough in intent or style. There may have been, but we didn't find them. That we at least found his. And from his study we could pinpoint some unexpected negative effects and see if they occurred in our project - or is the intention of the Friends wouldn't be the intention of this Ethical group, but they happened. For example, one thing that, I think Hank was looking at - I guess, but it's a long time ago, we may have done it on our own. But one thing that would be negative would be if the participants in this summer camp came out snobbish. Now, I know how things go, you know... And, look, they wouldn't really want that. They wouldn't want that. So we had to, you can't just say, are you a snob now? Yeah, I'm a snob now! No, we had 
questions that we would interpret that way, what it was. I don't know... It didn't happen, anyhow, so fortunately, we didn't have to take that any further. That was comforting to say, you're not doing any harm. You're doing all this good, and you're not having the bad effects. That's good. So we did that, we worked out our overall design, which consisted of - I don't remember now, exactly how many, but - three or four surveys with the participants, including one survey before they ever got to the place, two surveys while they were attending the summer camp, and one survey about two months after they were back home, to see whether things lasted or they encountered problems that they hadn't expected and all that sort of thing. So it was, it was a tight little job. And we built in different kinds of controls. You can't make a laboratory type control when you're doing fieldwork. Fieldwork is messy. One of the things which seldom gets talked about in the literature is that there's no such thing as a pure control group. Because, during that six months, if you have a control group, something's happening to them. Who knows what? [Inaudible] So you got to somehow compensate for that. And we figured out ways to try and do it, and I think we did a workmanlike job. Maybe not quite as good as the Wizard of $\mathrm{Oz}$, but not all fantasy either. It was OK. What else? Anyhow, we were happy when it came out... That this... We were just, both Herb and I sat down and said, suppose this all comes out bad for their group. How can we face these nice people and say you've wasted 10 years or whatever? But it didn't happen. And they were happy to get the report. So happy that they created more encampments, one on the West Coast, up around Berkeley, I think, and others. That was several years after we'd done the initial study, I was up to my neck at work in California, so Herb got another co-author involved, Terry Hopkins. Terry's dead, unfortunately. Or you could talk with him about that. But, basically, he did, among other things, but he was mostly responsible for the follow-up with college students, [80 MINUTES] and what difference it made with them, and so forth. So it was good. He added to the study, and it was fine. Having done a much larger study, Herb and I decided to put it together into that monograph, which we did. I made the drastic mistake of suggesting a publisher for the manuscript. They accepted. They published, but they didn't publicize. So it didn't go very far. Never made the New York Times bestseller list, put it that way. But we were happy to have it academically published and available to other scholars and we weren't looking to have a racy, bestselling novel. It was a piece of work.

POOLEY: You mentioned Herbert Hyman.

\section{WRIGHT: Who?}

POOLEY: Herbert Hyman. Herb? And, I'd just be curious to hear how you first met him, whether it was through a course and, you know, the collaborations you did with him even before this project, with the Encampment?

WRIGHT: Herb came to the Columbia graduate department somewhere around 1952, I'd say. I was by then - I had my master's degree, that's another story - but I was a doctoral student. That would be in, that would by my third year, I think, yeah, it would have been. He came to, among other things, to bring his knowledge about survey research to the Graduate School program. And he taught the basic methodology course. He taught some other courses too. And 
I took some of the other courses. He took a ... he ran a seminar on secondary analysis, and so I took it. And, anyhow, we just clicked, from the beginning. We found we were on the same page, but enough difference that we would complement one another, I think. I would say it was one of the luckiest things, one of the most blessed things that happened to me. It changed my whole life. I don't know how much you want to get into the graduate department. I was ... well, I'm really going to backtrack now, you're going to have to straighten it out. Some students didn't like Columbia graduate department. They thought the teachers didn't pay any attention to them. All they did was their research. They weren't worried about their courses. Nonsense. I went in, and I got my masters degree, and the department put me up for fellowship for the next year after I'd had that one year for the masters degree. So I was all set. I had just gotten married, and here I had a fellowship coming to me. And Bob Merton called me in, and he said... He was chair at the time. Or maybe it was Lynd? I think it was Merton. He says, I've got bad news for you. The department didn't get any fellowships. And you were our candidate, but they didn't get any fellowships. They were on an economy kick at the main office. [grunt] I'm crushed. I go home. What are we gonna do? What are we gonna do? What are we gonna do? I'm down in the dumps. A couple of weeks later, a phone rings. He says, Charlie Wright? And I said, yes. He says, Paul Lazarsfeld. He says, oh good. He says, I'm in a terrible fix. I hope you can help me out, this is a terrible ... I said, what is it? He says, well the student I want for my assistant next year, he can't make it, and I'm desperate. Would you please be my assistant? What I please be his assistant? You know. But, that he was so thoughtful to turn it around, that I was doing him a favor, [85 MINUTES] when he was literally saving my butt. He could do no wrong. And so I became his assistant. Did that first for his courses, where again there are some side lessons that I want to get on record here. And I'll tell you about them. But then he became chair, and he said - and Manny Rosenberg, who had been his chair administrative assistant, rather - had finished his degree and was off doing something else. So he says, Charlie, will you be my administrative assistant? I said, yeah, why not? So I took that. The next year, Merton was the chair, and he says, you got to be my assistant. You've got all this experience with Paul. I said, ok. [Inaudible] Easy street. On that street I saw the back door of some things, not always intentionally. I heard Lazarsfeld and Merton discussing another student. I didn't want to hear that. But they didn't mention his name, so that was alright. And I heard Paul say, I'm so desperate, I want to help this fellow, and he'll probably finally get his degree, but, he just, he will never practice sociology the way he should. And Bob said, yes, I understand. He doesn't realize that getting a PhD is a way of life. And I think to myself, oh my god, what have I gotten into? They think you're going to spend your life getting a PhD! It wasn't until later, I thought, reflected on it, what they were saying was, he's got to be socialized to a style of academic life if he's going to get anywhere in academic life. That's what they meant. They were worried about this fellow. They weren't trying to knife him or chop his head off or anything. They were concerned. That impressed me, very much. And, for the rest of my time when I got to be a professor, I didn't think my job was to get rid of somebody who just didn't live up to snuff. It was to find them the right path where they could succeed. We don't want to turn out failures. We want them to succeed. So that was, again, an unintended lesson about academia that I happened to overhear, shamefully. But I did happen to overhear, when I was an assistant. 
Was impressed me. The second thing that impressed me was different styles of leadership. I loved Paul, especially after he saved my life. So I was thinking, I, I you know... That's neat. And he gave me some things to do while I was assistant and when I was just a student. Didn't bother me. We were taking, I was taking a seminar, and had done some analysis of voting for the book that was working on with Bill McPhee, I think, and some others. And the peace that he wanted me to do was to look into class consciousness. And he was puzzled, and I think somewhat appalled, that we didn't have the organization and sense of brotherhood among the working class that he had seen in Europe. Probably true. They had it in France, they had it in Austria, I'm sure all over. So I spend a good part of the semester doing library research on that, and that was OK. But then he gave me access to the data and I worked out a project of my own to present at a seminar that night. Big seminar, with Lazarsfeld, Ernest Nagel, other people. I think Nagel was there. [90 MINUTES] I may be confused. Again, there were different seminars where Nagel came in. And so, it's my turn. I go up to the blackboard. We had blackboards. We had chalk. Up I go to the blackboard, smug as can be. Because I had worked that boy, I got that, I was going to show them. And I go... At one point I had run the data separately by gender. We had only two in that days. They were males and the females. And I run them off, and he says, stop! He says, why did you do that? He says, why'd I do that? Yeah, you know, why'd you bother doing that? I said, well, everybody does that. And they did. You couldn't pick up a study where they didn't put the man on one side and women on the other. He says, no, no, no... That's, that's no good. I'm standing in front of this group [laughter], and my teachers telling me that's no good. What am I going to do? He looks up, and he says, well, tomorrow you do it the right way. Tonight, go ahead, do what you did [laughter]. I'm I'm [inaudible]. Then, it wasn't until later, that I figured out what he had said. Why did you do that? I didn't have a theory that men and women behave differently on this thing. I wasn't expecting to find differences. Why did I do it? I might not have had a grand theory, but I should at least have had some reason to do it. And I thought about it. And it stuck with me. You don't just do something because everybody did it. You do it because you have a reason to do it. You want to separate by age? Why do you want to compare the old and the young? There's gotta be a reason. You expect to find a difference because their socialization is different? Ahh! We're getting down to something here now. I wasn't smart enough to see that as a student. And it took me a year or two to realize what it was. What a dope I was! But he was gentleman enough to let the student off the hook... Go ahead, play that tune if you think it's worth listening to. That impressed me, and again fed into my counter belief with the other students that somehow they didn't care about, they only cared about was the research, they didn't care about the... They cared about people! Big mistake. The same kind of philosophical look, I guess, that made them think that you couldn't have both Merton and Lazarsfeld on your thesis committee, because they' $d$ be fighting. You wouldn't be able to please both of them. They never got along. They got along beautifully. There's no problem. And they were both gentlemen enough to, and experienced enough, not to crush a student. And I tried that. And I don't know if it always worked, but I tried it. All again get off track here. About several years ago, l'd given my little seminar, and it was small. But it was the way I wanted to teach, and I had encouraged them to discuss their ideas and that sort of thing. Course was over, grades were in, no problem. This fellow I didn't know 
before, from another department, came in and he said, I just, I'm going home now, I just want to stop by and thank you for saving my life. I said, what do you mean, saving your life? He said, well, the semester before last, he said, I had a seminar with Prof. X - I won't mention his name, was not a professor at Annenberg school - another department - and he said, he just crushed me. He stepped on anything I said and just ridiculed me. At the end of the term he said, [95 MINUTES] I felt I must have chosen the wrong field. I think I'Il just drop school and drive a taxi or something. But he said, you never embarrassed me, you never ridiculed, and you listened to what I said. You didn't always agree, but you listened to it. And he said, I want to thank you for that. Well, that was the fruit to the seeds that were planted on me back in graduate school. And I'll never forget it. I'm babbling, but nevertheless, that's. I've come to the conclusion that you, things that either hurt you very much for that you like, did very good for you, they stay in your memory 80 years later, 70,60 . They can, they might have seemed trivial at the time, but they had their impact. So I got a little piece from Casey and his trust that I would do the job that I should've done right then and there. I got good help from Lazarsfeld, courteous treatment, good from Merton, wrote me nice letters after I got my job in California. That was very good. So I was happy with that. And, I've had a blessed life that way. Very good. I can't complain.

POOLEY: Can you say more about your relationship with Herb Hyman

WRIGHT: What?

POOLEY: Your relationship with Herb Hyman? In those years he arrived, you said, in 1952 or '3 and you took courses with him...

WRIGHT: Herb, Herb was like the brother I never had, OK? We not only clicked professionally, but we clicked socially and personally. Helen, his wife, and Anne-Marie, my wife, got along superbly. The two of them would be making the dinner for Herb and me, or whatever, when we were working, chatting away, having a good time. They... And I watched his three kids, different stages of growth, and we talked about work but we also talked about life. And I miss him very much. And I never found another person I could work with that well. I'm not exaggerating when I say, he'd be writing something at the typewriter and get called away at a phone call or something, l'd sit down and finish it. Not the book, but a paragraph or whatever. We just thought alike. But not me-too-ism. We would discuss differences. And work them out, what to do. We had, basically, similar views on all kinds of social things, but occasionally there'd be a difference. I'm a South Jersey boy, people in my family hunted, had guns. Herb was strictly antigun, yeah. So, we were different. That's all right.

POOLEY: Do you remember...?

WRIGHT: And we liked bargains in shirts. We could go to... They had retail discount, no, factory outlet stores up in Connecticut. He and I would haunt them. Trying to get the cheapest, the best-looking shirts on the market. That's kind of fun. To do that with your ex-prof is double fun. 
POOLEY: Do you have any class in particular that you took with Herb in the Graduate School. That you remember fondly? You mentioned the class on secondary analysis? And it seems as if you wrote a paper out of it around that time with another graduate student named Williams?

WRIGHT: I don't know... which, which project you were talking about? We deliberately planned to do our joint work in the summertime. The clear objective of that was not to be interrupted by telephone calls or students coming to the door and so on. Because, even though they've forgotten it now in some places, [100 MINUTES] the fact is most academic appointments are for 10 months, and the only reason they pay you the other months is they've taken it away from the months you should've been paid. They wanted to work out an even flow of income, but you should... your summers are free. So we would do our work in the summer. And both of us thought, might as well do it in an exciting place for a fun place, interesting place. And one project - oh [inaudible] I don't remember which one it was, because there were a number of them where we had printouts. It might have been the effect of education later in life. We had reams and reams of computer printouts, and we... Herb had found a place for us to work off the coast of Greece, yeah. And there we were, it turned out, the place couldn't be reached by land. You had to go over water, and the only way to go over water was in a rowboat. And the only way to get a rowboat was to hire a fisherman who was out of work at the time. So, he'd come with his big pile of printouts in a rowboat being swamped with water. That was interesting. And we didn't lose any data. Nowadays, you wouldn't have all that paper to tote. I don't know what you're fishing for. Let me put it this way. When I, before I started any kind of college education and so forth, I was impressed by print. And I thought, wow, wouldn't it be neat if someday, in the distant future, your name got printed. Maybe like in a footnote. Wouldn't that be great. Now that's lurking back here in my brain. I go up to Columbia, and... But a few people had their name in a footnote. Thought that was good. We could do that. Paul Lazarsfeld, who had me working on this class consciousness thing, out of which I wrote a paper, but not for publication. Just for his eyes only. When his book came out on voting, there was a little section on class consciousness. He put a footnote in there that says, thanks to my assistant Charlie Wright, yeah? I saw my name in a footnote [gasp]. Seventh heaven! I decided I didn't want to be, and probably didn't have the ability to be a, superstar. But I've been very happy to be what they used to call in vaudeville a second banana. And, so, it never bothered me if we wrote something, whether Herb was first or I was first or somebody else might be. I was there. I was present. And that meant a lot to me. And Columbia did that, and Herb's generosity did it a lot too. Some articles we would just flip a coin who was going to be the first or we'd take it alphabetical or something like that. It didn't bother me. I was proud to be attached to somebody whom I respected. The ideas, or some of the ideas, that Herb either invented or extended or something, have played a very important part in my thinking, but - and now I digress - [105 MINUTES] I made my mind up very early in the game that I would make my writing as simple as possible so that the average intelligent person could read it, and not have to figure out some Germanic twists to go on, where a paragraph takes the whole page. And you get down to the bottom, you got to go back to remember what they said. I didn't like that. But putting things in the language that people can understand detracts from your... What should I call it?... Glamorizing as an intellectual or whatever. I don't, didn't bother me. So the ideas of reference group and the ideas of reference individuals, for examples, I use them but I never 
called them that. I just used them in my analysis, and didn't... I should have put it in, put a footnote, for the intellectual, this means reference group [inaudible] ... talk about, talk about the family or the friends. We have, now with the digital stuff, we have all these networks going out. Well, networks, that's good, that's a good idea. But you had with [Jacob] Mareno years ago very similar ideas. The only thing that stopped him was it got out of hand. You couldn't make picture diagrams of a real big network. You're done! It's going to [inaudible] up. Mareno turned it all over to the social psych section of the ASA [American Sociological Association] and it's gone far. That's good. Now with this network thing, that's going to take off. And I don't know what the future will look like, but I think networking is, it's been here and it will stay here, the idea of reference individuals, reference groups. The only, not the only, but a major danger is that people will use the terms interchangeably when they're not really interchangeable concepts. You got to go back to the original concepts. I went back to [Walter] Lippmann's book on the study of man. That was the earliest I could find use of status and role. Is that ever vague? Yes. You can see why others, as they begin to use them have modified them such and so forth. So our terms are initially often very vague or very limited - it could be the other extreme. But I try not to get into those theoretical but linguistic arguments that go on. I don't know if I succeeded or not. I know I was not able to avoid it completely, but in my little book I tried back then to just... I wrote that book for students, strangely enough. And the second edition and the third... As I said, the editor didn't like the third because he wanted marketable ideas. Get another author. He did. I could've been rich, rich! But I didn't do it. Yeah, it was fun.

POOLEY: In the 1950s, you were in the sociology department. You had an interest in communication and you were working with, and being trained by, two psychologists, Lazarsfeld and Hyman. I was wondering what the relationship between, in particular, sociology and psychology - both the kind of sociological social psychology and the psychological variant were for you?

WRIGHT: Yeah, what's your question again?

POOLEY: Well, well, I mean, the relationship between sociology and psychology, as two of your three disciplines, what that was like for you?

WRIGHT: It's that last part I'm not hearing.

POOLEY: Oh, in the 1950s, [110 MINUTES] what, what, as you were trained by Hyman and by Lazarsfeld, both psychologists, how did you integrate and think of yourself in terms of these two disciplines?

WRIGHT: I thought of myself as a sociologist, no doubt about it. But I minored in social psych., but I never... And I used some of that when I was with the NSF, because I had to find out what was going on at that point in history and what would be new research and what was... So, I didn't abandon it. So I thought of myself as a sociologist. I probably slipped into social psych. to in my own thinking. I didn't see a conflict. The only conflict I saw was going on in the academy where they couldn't decide, should I be in psych. or should I be located in sociology? The social 
psychology I'd studied was well, kind of broad, I'd say. I studied with Otto Klineberg, an interesting fellow and all that, but he was more of a global figure himself and did work on race and things like that. Don't think I had any other social psych., but - oh, you know there was another man, I've forgotten his name. Yeah. I think had there been a social psych. program that leaned more to the social and less of the psych., I would've been comfortable and able to work in there. But the other way around it worked just as well. And why should we let academic distinctions shape the way we think about reality and so forth? What, as I said before, what I was trying to do with the graduate students, especially the doctoral students at Penn, was at least to keep them open to have, to bring those variables in like ... I should have had an answer when Lazarsfeld said, why did you put [laughter]. I didn't have an answer. I should've had one. But the students that I've worked with - not all of them, but they always work on their own problems. I don't give them a problem to do, I don't have a multimillion dollar project and slice off a piece. I find out what they're interested in and help them to shape it into a workable project. That's OK. In shaping their thoughts I hope they will take into consideration the background of people and not just go immediately to the brain or to the heart. What's the heart got to do with you, anyhow? Oh [inaudible], sorry heart! So, I tried as much as possible not to ignore the communication scholars. I got along well with them and I read their work and I like it. But I wanted to add the sociology part to it. Now, that's a very fine tightrope to walk for 40 years or so. You get tempted to be seduced into doing things the way they're going into communication, and I tried to not lose my sociological perspective. Put it that way. If I had another lifetime to develop it, I probably wouldn't have got any further, either. Just the way it is. And... [inaudible] I couldn't have been happier than I was at the Annenberg School. It's really, really been a good place. I've been able to do my own thing [115 MINUTES] and a large part of my work is, doesn't explicitly deal with communication but implicitly it's in there. Like in that Encampment study, at the very end we concluded that the didactic part of the program was important, but so was the social activity that went on in the barracks overnight. They talked to one another and the face-to-face communication... Mass media not so much. A little bit. What it is now I don't know with all the digital, with the wristwatch you can talk to [inaudible]. If I had another 60 years I'd look into it, but I don't have another 60 years. That's what I am.

POOLEY: Let's take a break there. We've done a full two hours, and there's so many rich topics that I want to return to, so I'm sure that we're going to have at least two more sessions, if that's OK. To pick up, in fact, talking about the Mass Communication book itself. You mentioned it came from your students and, or you wanted to write for your students. I'd love to pick that thread up. So let's plan on talking again.

WRIGHT: Oh, yeah, I'll talk about that. May not always make sense and there are some smaller sections in there, I had to finally give a little bit to the poor editor so that he or she would earn their salary, whatever they were doing. I wanted to talk about my own point of view in the book, and I did. And just never brought a fourth edition, that was... Now I don't know what I would do with all the digital stuff [laughter].

POOLEY: Well, thank you for today. 


\section{END OF SESSION ONE}




\section{Transcript of interview conducted July 19, 2016, with CHARLES R. WRIGHT}

Haverford, PA

Interviewed by Jefferson Pooley

POOLEY: This is day two of an oral history interview of Charles R. Wright, conducted by Jefferson Pooley in Dr. Wright's home in Haverford Pennsylvania. The interview is part of the Oral History Project of the Annenberg Library Archives of the Annenberg School for Communication at the University of Pennsylvania. The date is July 18th, 2016. So, I wanted to start out today asking about your parents and whether they both had full-time jobs, and what kinds of work they did?

WRIGHT: Well, that's a good start ... I'm not sure I can answer it completely. I was - am I getting through there? Yeah. I was born in the Roaring Twenties, but I don't remember that. But they tell me that was when I was born, so I believe that. Those were relatively good economic years in the U.S. but they didn't last very long. From our point of view the Economic Depression started around 1930 or '31. My father was laid off. They didn't sugar-coat it in those days by saying they were "downsizing" or anything. You were just "laid off," done. So, like thousands of other men, he started looking for work, but there was not work. And I have memories of our going around in downtown Camden, New Jersey and over in Philadelphia and I saw blocks of men lined up hoping for work for even a day ... Job in the commercial world until the late 1930s just before we got into World War II. But, part of the time that he was unemployed was taken up - fortunately - by Works Project Administration [WPA], which at the least managed to put food on your table. And at the best sometimes turned out to be interesting jobs that the WPA was doing because the private economies couldn't afford it. Like the road work, bridges, and libraries, murals were going up. The WPA employed people in all walks of life. That was very important because, we know from sociological studies, and other studies that when man loses their employment they gradually sink into a kind of social isolation, their lives get less rich and they get depressed. So that really helped us a lot. It also ... there was a second program called Surplus Food Program. Farms were producing lots of food, if you didn't have the money to buy it. That surplus commodity was distributed to people who were in hard times. Uh, there was a third kind of program put in by the federal government back then called CCC, Civilian Conservation Corps. Saved spirits, and saved lives at the time. So, we got through that and then my father got a regular job as a mechanic. [5 MINUTES] He worked on the brake systems on these big tractor trailers and also on private cars ... He knew a lot about that and it worked out very well, until a freak accident put him out of work again. The 
accident was that he was driving a pickup truck with the breaks, wherever he was going to another garage or going back home, I'm not sure, and the truck, his truck, got hit by a fire engine. Threw him out of the truck and onto the sidewalk, and after that he couldn't proceed to lift big wheels and things like he did before, so he took a forced retirement and went south where they thought the economy would be stronger and where the climate was certainly better than up here in New Jersey. My parents stayed down there for a while, and the last thing he did in Florida was get a little ice cream truck and went around the neighborhoods. The children liked that, they'd come running out to get the ice cream, and he enjoyed that part too and it got him out of the house and got some income and he likes children and he thought that was OK. And then his health turned bad and he came back up north where he thought medical attention would be more to his liking. So basically ... my family was a modest income, workingclass family and their friends were about the same station in life as that. My father was, himself, born in the late 1800 s when it wasn't common that all the children went to school. So, I really never really knew how far he went but it was probably what we call in the elementary school, maybe up - who knows, I don't know [inaudible] didn't know enough to ask him the right questions and I didn't want to embarrass him in any way whatsoever. He was a hard working, honest man. My mother did not work after she got married. When she was a late teenager she worked in Philadelphia in some kind of clothing business - I never was clear in my own mind - she just said they made men's clothes, and I let it go with that. But after she got married the home was her work and that was OK. They never skimped on schooling, they wanted me to go as far as I could and was able to get through high school graduation. There was some strain on the family, but we made it alright. Um, any more specific things you'd like to know?

POOLEY: Do you know anything about the family history? You know, the ethnic heritage of your parents? When their families came over from Europe?

WRIGHT: No, they didn't come over from Europe. My family - my father came over from Philadelphia, my great grandfather Wright was in the Civil War, in the Union, but what he did or what he was like I have no idea because he was dead before I was born. [10 MINUTES] My father's mother came from English background but I think she was born here in Philadelphia herself. But her mother was from England somewhere, where I don't know, never could find out what town they came from. My father's father - all I knew was that he was born in Philadelphia and his father as I mentioned. And on my mother's side, her father was English background, perhaps a Quaker but perhaps not. He was, he died when my mother was a child so she really didn't know a lot about him and didn't have much to say. He worked for a publishing company in Philadelphia, he was a pressman with them. Her mother, I think, was born here but her parents would have been German but I'm not sure where they came from - 
what town or what area. Um, my step-grandfather, the one who replaced my grandfather when he died, was a, he worked for a paint factory and had much to do with their selection and mixture of colors. And I can remember to this day that he had a little room in the house that he used for all the available colors we had. He put that on his desk and put a sheet of glass over that, so you look through the glass and you saw the colors and I just didn't know there were so many colors. It was just fascinating. In addition to his work, which brought him from south Jersey over to Philadelphia and got used to that and went through what is now Society Hill, and took a ferry boat from Jersey shore across the river to the Pennsylvania shore and he used to take us as children, once in a while, to short walks around the Society Hill area to look at Benjamin Franklin's grave, for example, and of course Independence and Carpenter's Hall and all that. And in those days, things were open and free and secure. So, we just wandered through those old historic buildings. There were some, security people l'll call them, who would stand at the door and mostly what they would do is say, "Don't touch," and so we as children would, had a tendency to go over and touch the chair or sit in it or whatever. No you couldn't do that but you could wander freely though, and, no one took advantage of it in a evil way. It was just a part of our growing up. We went several times to historic areas ... that's about the extent of - oh, my mother had a, had a sister but she didn't work she raised six children and that was plenty for her [chuckles] to do. You wanted to ask something?

POOLEY: Yeah, I mean, moving onto the Navy, you had talked last session about your decision to enlist and also your reaction against the hierarchy that you experienced there. Was there anything else about your role in the Navy during those couple of years that you recall that you think might be worth mentioning?

WRIGHT: Not really. I did get my belly full of technical stuff because they trained us - I came out of the Services Aviation Electronics Technician Class II but I never followed that up in civilian life. [15 MINUTES] It got mixed up with my attitude about taking orders [laughs] I didn't like that. I don't think it influenced me in any other way. I'm glad I went in and did what I could to help in the Second World War but I couldn't see it as a career. That would not have been good for me. Career choices, I didn't - unlike some college studies in the day - I didn't go in knowing I was gonna be a doctor or a lawyer - I didn't know what I was going to do! I wanted to have enough freedom to be myself, and I did.

POOLEY: And last time you also talked about the Columbia Graduate Department of Sociology, and you mentioned in passing your master's, and we didn't have a chance to talk about it and I wondered if you could say something about your master's project and who the supervisor was if you remember any of that? 
WRIGHT: Yeah, I might have the dates a little mixed up because that was a long time ago! Columbia was a major sociology force back in when I came out of the service. I came out in 1946, started graduate school that fall, fall of ' 46 . The department at Columbia at that time had Paul Lazarsfeld, Robert Merton, Robert Lynd, of Middletown fame, Robert Maclver, that was his retiring year as I recall - I took his courses. Who else? I'm stuck, hmmmm ... Edmund Brunner, but he was over in Teacher's College most of the time, did give a graduate course or two in the sociology department. So did William Casey, who was mainly an undergraduate start lecturer, but who also gave graduate versions of his work. I'm sure I'm forgetting somebody, those are the people I recall at least, at the very beginning. By the time I got out, that was five years later, they had added Seymour Martin Lipset and Sigmund Diamond, a historian from Harvard, William Gould [sp], a sociologist. Now I'm drawing blanks again, sorry. It'll come back ...

POOLEY: Who did you work with on the master's?

WRIGHT: I started with Lazarsfeld and increasingly worked with Morris Rosenberg, Manny Rosenberg, who had gotten his degree at Columbia at that time and was starting up teaching. Those were the only two I really worked with on the master's degree - an ultimately stupendous project that I wouldn't dare let a student try to do today. It involved a content analysis and I must've acquired a hundred or more magazines that I was doing this content analysis with and I was working on day and night. It took forever! But I finished it. It was preposterously positive about all the findings. [20 MINUTES] I wouldn't go so far today, but it was a student's effort and I did a good job on it, and Manny helped. It was good. I did it in a year. The normal was two years. But my GI Bill was running out, I had just one year left. I thought, well, I better get the master's degree. I didn't even think of a doctorate - master's degree - that would put me one step up on the occupational-seeking ladder. With a bachelor's degree in 1944, no I got my dates, in 1944 I got the bachelor's degree. I'm getting mixed up on years again. [sigh] ' 44 I went out to the service. That's it. I started graduate work in '46 and then that first year I did the master's degree and then I got it straight. It was called "Mass Frustration Caused by Public Advertising" - impossible. [laughs] I didn't know it was impossible, I couldn't do it! And I did it. Probably why I can't see so good today, sitting up there all night looking at, doing content analysis. But it worked. Now we sort of slide over into the graduate department. I think I told you last interview that I really didn't know what I wanted to do beyond the bachelor's degree, and I had taken this diverse spread of courses to taste different fields, didn't like the taste of economics and so forth. I was very interested in public opinion and communication. Went to see my undergraduate teacher, William Casey, who said, No need to look any further, you stay right here at Columbia, just go one block down the street from the undergraduate college, and we have some of the country's leading researchers, at that time in this field. And so I did, I went there. I didn't have any of my undergraduate teachers 
again - I had different faculty over there. When I went in it was, [inaudible] Lazarsfeld, Merton, and eventually ... eventually Seymour Martin Lipset ... eventually, Phil Kingsley Davis was there in those days. It's coming back slowly.

POOLEY: What made you decide to stick around for the doctorate after you had completed this content analysis?

WRIGHT: I couldn't get a job! I thought, Well, I couldn't get a job, and I can't afford to go any further but I will try. That first year I was on my own with the GI Bill, that was OK. But I had established myself as a person in the field, in the study in the field anyhow. I know I told you this last time - Lazarsfeld called me and saved my neck, to be his assistant, and from there I was in pretty good shape and moved from one assistantship to another and so on. I had been up for a fellowship the second year but we didn't - it was hard economic times again and they didn't have any fellowships, so that was alright.

POOLEY: You mentioned the course with Lazarsfeld, and you also mentioned a couple of classes with Herbert Hyman. I wondered if there were any courses that stood out for you, or even any other fellow graduate students from that period, that stood out for you as future collaborators or just as impression-makers?

WRIGHT: Well, you pretty much hit all of them, because it was an all-star team. [25 MINUTES] People sat in the hallway, they could hear Merton's courses, the rooms weren't big enough to hold the students! Lazarsfeld was a natural for me because of his line of research. Oh we had Daniel Lerner who gave a course on Psych War, Psychological Warfare in World War II, and that made an impression on me. I took work with Lynd. He was like grandfather of the field. I took Maclver. That went over my head. He had obviously been thinking a long time on what he was talking about. His course was on social change, and it was a mixture of European ideas and American research. It was a good course. It was OK. Had a course with Lipset later, some other folks that slipped by me. I should mention that my minor was in social psych, so I had taken the psychology, straight psychology course in the College with [Fred] Keller, I've forgotten his first name. A super lecturer, and a real scientifically oriented person. He gave a course with a lot of emphasis on Pavlov and conditioning and he brought some orientation from Bales up at Harvard, so that was a good, that was a good course. I took a couple of courses with Otto Klineberg, an internationally known social psychologist at the time. Later he went to Europe and, I think, worked with the United Nations. His specialty was race relations, and what is race. You hear the same questions today - half a century and we haven't solved that problems. There were some other psychology type people I don't remember, to tell you the truth. There's 
not doubt the whole department's weight was in sociology, and social psych was a secondary minor for people to take, and I took it and it was OK.

POOLEY: Was there a secondary minor in communication or mass communication?

WRIGHT: No, no. There were no schools devoted to just communication that I knew about. It's possible there was, were some on the West Coast but I don't think so. It was primarily Columbia, and heavily influenced by wartime research that they did on morale and civilians and studies on that type. [Inaudible]

POOLEY: When it comes to your exposure to opinion research, to survey research methods, did you get most of your exposure through the Bureau or through coursework by Lazarsfeld, or coursework with Hyman, or where did you pick up your survey research training?

WRIGHT: In my opinion it was most heavily from the course work. But l'd also got my hands on real data and did survey stuff and the like. The formal training came, I think, from the work with studying the work of Lazarsfeld, and doing the work with Hyman. That was a good combination. [30 MINUTES]

POOLEY: Hyman was working in this period, maybe in the early to mid-1950s, on a compendium or almost textbook, on survey research analysis. Something that was published in 1955, and I don't know if you were involved at all or if ...

WRIGHT: I can't spot what you're talking about. Herb wrote a lot of different ones ... secondary analysis book. Interviewing, I think, I don't remember.

POOLEY: It was an overview of survey analysis and survey research.

WRIGHT: He did his memoirs around that. That book I know he did. I'm having trouble zeroing in on this one that you're recalling.

POOLEY: You spoke so movingly about your connections with him, and I wondered if since he wasn't in the department when you started out, if you remember your first encounters with him or the very first, or initial course you took?

WRIGHT: [Sigh] no. The impression that was going around amongst the students and others that we were getting an expert on survey research coming in from NORC [National Opinion Research Center] and the background that he had. And the next thing you know he was giving 
the course and we took it. I liked it, I learned a lot from it, and then I became his assistant after Lazarsfeld, Merton and then it was Hyman ... and it was a lucky day for me that that worked out because, we were just very compatible. It worked out very well. I used to kid and say Herb could start a paragraph and I could finish it for him. You know, it's ... which was true. But, it's a really strange thing, training for ... I didn't think I was going to be a survey researcher and I never really was - did projects that used it but I didn't tout it as the way to go. So, it's funny how you learn, and what I'm getting to is that my association with Hyman taught me a lot about balancing work and family and relaxation and all that. He was not a too briefcase-carry-homeevery-night guy. He had other interests and a nice family, we got along, OK it was good. And I thought, yeah that's, that's good. I don't want to be a workaholic, but I want to do enough to achieve some satisfaction and some pleasure out of what I'm doing and not neglect home life and occasional baseball game or something like that. And that worked out well. It turned out that the two families got along fine, and we usually arranged it, not every summer but some summers, we would take a place in an interesting area like Italy or something, and Herb and I would just squirrel away and work from nine or eight in the morning till lunch time and then after lunch we would work till six or seven and quit. That was it for the day. And that was a good balance.

POOLEY: Speaking of Herb, you were beginning to teach probably in this period while you were still a graduate student at Columbia. Were you called on maybe in towards the 1953-54 period to teach in the department? I don't know if there were any memories you have about that early teaching ...

WRIGHT: Oh yes, oh yes ...

POOLEY: ... and the courses? [35 MINUTES]

WRIGHT: If I recall correctly, in 1952 or 3 I gave my first course in the College, in the first year or maybe or maybe first two years - very beginning, anyhow - I taught this Contemporary Civilization in the West. Way over my head. But I knew something of that stuff, and I have to give myself a C+ [laughs], and I figured out later what the problem was. The problem was that I was really set on, You've gotta have data, and it's gotta be produced in a scientific way - not with a particular methodology but where your work could be replicated ... if somebody wanted to, they could challenged it, they could work on it, that sort of thing. You had to have data. And that Contemporary Civilization program, that was a lot of talk. Bright and famous philosophers in the past, back to the Greeks, back to the Romans, here and there, but not much data. If we're going to discuss something, and these young students would be giving their opinions and l'd say, Well where [laughs] where's your data, what's evidence of it? So we didn't, we weren't 
on the same page ... I just never had been comfortable with the grand theorists who don't have anything to back up ... but they have brilliant ideas! And it's worthwhile to know about them, and it's worthwhile to teach them, but not in my world. [Laughs] So yes, I had difficulty there. I thought for many years that the difficulty came because I couldn't direct the discussion or get it going or something, but no, that wasn't the problem. The problem was that we were on two different pages. And I came back full circle the last ten years or so when I ... not too slowly, but rather slowly, began to shift away from lectures and into smaller group discussion things where I did pretty well. And sometimes lost one or two students who didn't want to do that, but we did all right. I didn't like that a free, just-anybody's-ideas type thing. I had assigned readings and centered around them. I tried to pick readings that either used or failed to use some sociological concepts in their analysis. That's why - getting ahead of myself now - but that's why I came to Penn - I wanted the students to have the option of thinking of analysis in terms of society and its characteristics and so forth. Much of the work that was being put out in the ... what was beginning to be called the communication field - it still wasn't - much of that was biased towards individualistic psychology - looking for the personality of man or whatever, the brains or the genes or whatever. And less attention was being given - by some places, not all - less attention was being offered to students to think about the impact of the economy or the roles that they were playing, at occupations, things of that sort - not that they were any better than the psychological ones, but they were different. And I wanted students to go out equipped to think in those terms rather than just about the ego and the whatever they had in mind. [40 MINUTES] So, it took a lifetime but I came back to not only know why I wasn't so good in this first courses but to do something about it, and I did do something about it.

POOLEY: Did you teach in the sociology graduate program during that stretch, either during your dissertation phase or afterwards before you left for UCLA?

WRIGHT: [Sigh] no, I didn't list a graduate course. It's possible I was asked to come in and give a guest talk or whatever but my courses were undergraduate courses for those four years of ' 52 to '56. I knew I couldn't stay because Columbia rarely kept their own doctorates on the faculty. They might give you a step up as they did with me. I became an instructor - a term that's hardly used [inaudible] departments, so ...

POOLEY: Did you teach in sociology for the college or was it always Contemporary Civilization?

WRIGHT: Oh, no it was sociology.

POOLEY: What kinds of courses? 
WRIGHT: I taught a course in communication. I taught a course in urban sociology. It was a good course, I liked it. I'm not all certain in my memory whether I gave anything in methodology. I don't think I did, but I might have. But it was mainly the Contemporary Civilization course. Oh, I moved into the second year of that - not the same course again but a second one, which was not designed to be like a panoramic history, but was great ideas in, whatever - I've forgotten what they were now. So I had that - I had the CC still, and I had the urban sociology, and the communication course. I think that was enough [laughs].

POOLEY: And how would you put together a communication class when that field really didn't exist? I mean there might be people who said, I do communication research, but there weren't communication researchers. Do you remember how you would go about teaching this nonfield?

WRIGHT: Well, I taught about other people's studies and the nature of the sociological approach and that sort of thing. I was working it out. I didn't have it all packed up in my briefcase, so it was fun, and I liked those students better than the poor kids who were just starting out and had Dante's Inferno to talk about or something. That was good too. We'd get along alright there, but I knew that time was running out at Columbia and I had to find a job some other place and so I started the job hunt crawl type thing, and I was interviewed at a few places. Oh, I'll tell you an anecdote: I went to - I won't name the place - I was interviewed by a [inaudible], a very good sociologist, that was good. I told him what my interests were, what I had taught, what I could teach. That was good, we were going along very happily, and he said, Well, that's fine, he says, Of course - oh I forgot - you will coach the lacrosse team. I said, I'll do what? [laughs] I said, what's lacrosse? [continues laughing] [45 MINUTES] Crossed that one off my list, not much heartbreak about it. Too bad. It was a nice little school. I think I would have been happy there except I got hit over the head by a lacrosse - I think they carry a stick - anyhow ...

POOLEY: Well, before leaving Columbia, I was just curious if there were any graduate students at the SAME time as you that you were close with or that you remember as being, you know, outsized personalities or anything like that? Because it was an interesting group that went on to accomplish quite a lot.

WRIGHT: No, we were friendly ... As it turned out, my wife and I had some dinners or some meetings with Manny Rosenberg and his wife. I was friendly with Al [Allen] Barton but we didn't socialize a lot ... I don't know. It was just some good people, and there was this mixture between the department and the Bureau that went on and so there were some folks who 
worked in the Bureau who were part of the social world. But I don't think that there was - oh, Lenny Pearlman was one of our friendly people, we'd go to - Lenny, Lenny ...

POOLEY: Did you encounter Elihu Katz there much?

WRIGHT: Well, encounter is a strong word, but we would meet. We were not socially close. I was living up on Morningside Heights, and I think he was - I don't know where Elihu was - he might have been back in Jersey ...

POOLEY: And I was curious too about, you know, whether you felt like the Cold War context ever made itself felt, you know, in those years? I know the Bureau was in some instances using contracts from various government or military agencies - you mentioned the Psych War class from Daniel Lerner ... I just was curious given that the Korean War was going on, the Cold War had heated up right in those years. Was that a felt presence for you in the department?

WRIGHT: Not for me, no ... just ... we went other ways ... As sort of why I get into sociology, even though I didn't see the connection at the time, but there were a lot of us who just sort of felt that the Nazi propaganda had been effective in ... We could counter it in some way, but research didn't really show that. That it was that way, but that was one reason for getting in there, you thought, well, if the other guy is using it, let's use it too. But that wasn't a prime motive.

POOLEY: And I was also interested, since your book - which I want to turn to in a few minutes if that's OK - coming out later, was indebted to Robert Merton and his version of functionalism and his, I guess, the first version - the first edition - of that Social Theory and Social Structure book. I was curious about whether you took a course on functionalism with Merton or if that book had an outsized presence in the department ... ?

WRIGHT: Yeah ... that's very hard to say. I took the theory course with Merton and that blended in some functionalism but wasn't strictly that. It was ... his courses were unique and you always felt like you knew more than when you went into the lecture. [50 MINUTES] As I mentioned, people sat in the hallway hoping to catch some of it. He'd come up a long way, too; he was born of immigrant parents, I believe, and not too wealthy. They were, had a place in South Philly somewhere, and went to Temple and then from there to Harvard on a scholarship. So, it wasn't handed to him, here you are. He had worked his way up. Lazarsfeld probably came from at least moderate if not better background ... The other faculty I didn't know about. Later I got to talk about Herb's background. His father was a doctor in Harlem, I think it was in Harlem at that 
time. And you didn't ask people that thing, you just, learned through seepage [laughs] little bit of information here or there. But Herb, I got to know him very well ...

POOLEY: And what about the dissertation project? I'm wondering, you know, it was on the effects of training in social research methods on professional attitudes, and it was 1954, and I wondered if it was tied in in anyway - I think it was a Rockefeller or Ford or both funded project, and I also recall that Merton and Lazarsfeld had proposed a professional school of training to be this, what became instead the Center for the Advanced Study of the Behavioral Sciences out in Palo Alto, and that was maybe in the early 1950s. So, I guess I'm wondering, is it attached to that proposal that didn't get won but lived on inside the Bureau? Where did it come from and who was your formal advisor?

WRIGHT: I ... One of Lazarsfeld's lifetime ambitions was to set up an institutionalized - he called it professional school program. It would, had he done that, it would have stressed methodology for the sake of social science. It would go a little beyond what they had in the academic classes. Beyond that, I don't know what he had in mind, but he was concerned with whether it would work in a sense of turning out people beyond the Ph.D. who had a commitment to scientific research in sociology, and therefore he was receptive to any kind of research that would him to foresee, or perhaps avoid, the mistakes that led students not to want to be scientific in their research. So, that was one of the ideas that was out there and struck me as interesting, as ... with hindsight, I can see that in many ways - not always selfevident - the different projects I worked on tied into the socialization process. And there was also a big push at Columbia at that time for the study of professions. [55 MINUTES] Merton had a big study with Cornell Medical School and published some of the results about the same time that Chicago had published works on medical socialization. So [inaudible] did some work on socialization. So the concept of professional attitude was floating around out there and interested me. As I said, throughout - looking back at it - throughout time most of the work I did in some way or other tied in with changing people through socialization. I never spelled that out, but I look back and I can see that it was there. I think I said in our last interview, one of my quirks or idiosyncrasies is that I like to try to explain things to people in ways that they can understand and be interested in. So you won't find in any of my - well I shouldn't say any, that's too strong - but you won't find a lot of jargon. I tried, if I can't say it in simple terms, then I don't understand the concept myself, is the way I feel and I stuck to that mostly. Occasionally it gets heavy because the data are heavy, you have to deal with it ... But I only see this with hindsight, that I realized that's what I've been doing, is trying to say things in language that can be understood by the interested and intelligent reader and not - I'm not building some big theoretical framework. And I think that's the right choice for me. It has the drawback 
that it doesn't quite draw the attention of big thinkers, big thinkers like big words - that's too bad for me but ...

POOLEY: Well, I want to ask you about a book that was hugely influential - and I know I'm skipping ahead a little bit, and I want to return to your decision to go to UCLA but - I presume you were at UCLA when you began work on what became Mass Communication, the 1959 book, and I was curious if you could discuss how the idea came about for the book, and the working conditions writing it?

WRIGHT: I started a course at Columbia and it was really derivative of Lazarsfeld's work and Merton's approach and the like, and I didn't realize it at the time but looking back I can see now that there wasn't anything that took that approach at that time. You had people who gave journalism courses or TV courses or whatever it was. They were always centered around the technique used by the communicator. I didn't want that. I wanted to see what the sociological connections were and there wasn't anything out there to use, and it maybe was there but I didn't see it. So, I kind of limped putting the course together and those couple of years at Columbia ... When I got to California there still wasn't any book I could assign to the students to read, so I wrote that little book for students. And, I wrote it on two levels. I don't know how I did this. But I did two levels. If you approach the book the right way you'll find that there are scores of ideas [60 MINUTES] for dissertations in there - questions that haven't been asked. They all centered around some sociological approach but I didn't turn on a flashbulb and say, Look, here's how you do it! I put it out there for students to think about, talk about. I knew what I called it, a perspective. I felt I better do it myself, because nobody else was doing it that I knew of, and somebody might. And they did later, but I was first. And I tried to stick to that up to the last time that I gave what turned out to be a discussion course. The reading list lays out the framework well. It was part frustration that there wasn't something, and it was part uncertainty about whether, was I doing the right thing or not doing the students any favors by taking a different approach? I decided to stick with my approach and were I healthy enough to be doing it for the next ten years, I would feed in the digital stuff that is around now. The frame is there. Things have changed, people may and do have wider contacts with a lot of people with their [inaudible] and their Twitter and all that. So that's a change, but not a change in the basic orientation of what's going on. What I get... so, I have to backtrack. When I got the offer from UCLA to come out there, and I packed up everything and packed up our doggie and put them on a plane and off they went ... and we got out there and found a place to stay for a few days $-a$ motel which could take the dogs and all that - but I said to my wife, look we're in Los Angeles. I better go check in to tell them I'm alive and I arrived here. And so I go over to UCLA and I hunt around and I find the department of sociology, only it was sociology and anthropology. That didn't faze me too much because I knew I wasn't an anthropologist. I could live with them, so 
alright. So I go up to see the chair and I say, I'm Wright, I'm here, and he said, Oh, thank god you're here! He says, you'll be teaching demography, introductory sociology, and something else. I said, demography? I'm not a demographer. I have never even had a course in demography - I can't teach demography. He said, You see that building over there? That's called the library. Get over there and start reading. [laughs] And so I did. Was one of the courses I've ever given [laughs] because I was learning along with the students. We had fun. Then I had my communication course, which I was trying to organize my thoughts with, and I had the introductory course, which I thought, Well that's OK, I can do that. It's gravy, you know. They tell me it met at eight o'clock in the morning. Well, I was the new boy on the block and couldn't say much about that, but I said to the chair, look, You give me things I've never taught before, and he said, You're the new boy here. I said, oh OK. So I go to the introductory class I'm sure I told you this one - and there's about a hundred students... What am I gonna do? There's a hundred people. I don't know any of them. So the second time we met I said, look. I'd like to know more about you guys. I have a little - and it was short - one-page questionnaire about why you'd taken this course and what do you feel about the field and stuff like that. I take them back to my office - I shared an office then with another sociologist - and I start to read them. You know why they took my course? They said very clearly, eight o'clock you can get a parking space. [65 MINUTES] [laughs] That's why they took the eight o'clock course, so they could park their car out in the ... and get a spot. That deflated my ego a little bit. I thought, Well, that's what they want, that's what they'll get. But I gave them a regular course, a pretty good one too. So my little communication course was my little cave, my haven, to rush to, and I enjoyed writing the book. Updated it a little bit for a second version, and they asked me to do a third version, but now this would have been close to the 1980 s, l'd say, to the third edition. And that edition I had trouble with the publisher, who had done some kind of market survey or whatever and knew what the students wanted, he said. But I said, I don't care. I'd like them to hear what I've got to say, not what they want to hear. But we went around. I should have listened to him. I'd have been rich because introductory books back in those days were relatively rare and they sold like hot cakes.

POOLEY: So you decided to subtitle the book, the original 1959 book, "A Sociological Perspective," and you were mentioning a few minutes ago about psychology and how psychological mindset seemed to dominate the study of communication. So I wondered if that subtitle, and the motivation to write the book, were linked together?

WRIGHT: No, not really. Not back then. When I came to Pennsylvania I was much more conscious of the need to sell sociology to people who were now in what was becoming an established field of communication. I kept close ties to sociology intellectually, and much maybe even all - of the work Herb Hyman and I did together was sociologically motivated, and 
we used that. As it turned out, It was a kind of influence in communication in each of those areas. The first book that we did back in 1954, I guess it was. That was the Encampment book. It was a mixture of my interest in people changing and being socialized in a particular way, but it went beyond our first book on that, because the sponsors of the program had repeated their performance in California as well as in New York and so on. But, we were interested in change, if there was any change. The second book on changing communities was not in that it was a different approach. But then we get into the impact of schooling and that was once again not spelled out, [70 MINUTES] but it was a study in socialization which it turns out probably involved a lot of face-to-face communication too. So I stuck with that, and again it sounds kind of weird but I was as interested in people who didn't change as in the ones who did. That was an interest that I still have.

POOLEY: And it was a theme in the book - the 1959 Mass Communication book - where the emphasis was, in some ways, on reinforcement of social norms, and it was explicitly a functionalist approach you took, and you have this amazing functional inventory in the book. And so I wanted to know where or why you took the functional approach? Was it something that you had in the air, was it from Columbia, and then where this inventory came from?

WRIGHT: It was a little of all of that. You see a hint in the master's thesis, what did I study, I studied how people were frustrated by promises or offers that were prominent in advertising and that they would never achieve even if they bought the product. Advertisement for a car, scantily dressed lady drooped over the hood or something [laughs] And I asked, you know, what does that make you want? The girl! To heck with the car! You're not gonna get that girl. First of all she probably doesn't even exist - an artifact of the photograph and touching up the models so they look better than the real person maybe. But in any case it's not gonna happen. Same way with foods: eat this and you'll be Jack Armstrong, the all-American man. No you'll be fat but you're not going to be Jack Armstrong. So, that was irritating me. There was a book published by two psychologists called [John] Dollard and [Leonard] Doob on frustration and aggression [Frustration and Aggression, 1939]. Their theme was that frustration leads to aggression, and I thought, Yeah, it does ... How much are we frustrating people through our mass media? A lot. I spent hours going through those magazines. So there was a continuity there [inaudible]. I absorbed as much as I could absorb of Merton's functionalism and I liked it because, among other things, it drew attention to both the negative and the positive consequences of whatever it was that you were studying. And I wondered about that and I thought that's a good term. I think, without spelling it out, that I was influenced by Herb Hyman's ideas on reference groups and reference individuals and that crept into my perspective and into my perspective on a lot of things that I didn't necessarily publish. So I got the idea, Let's not just blue sky the good effects or downplay the whole thing [inaudible]. 
Depends how you're looking at it, from the bottom up or the top down, and I wanted to do that as systematically as I could based on what was available in the research market at that time. So I started, and I ended up with this humongous chart with all these things in it, and it was useful in both reminding you to look at both sides of things, and in organizing it in some way, but I never found it useful in setting up hypotheses for research and so forth. [75 MINUTES] I just stalled at that one, but I kept it because it didn't serve those earlier purposes. The rest of the book, some of it was rethinking on my part. I rethought a little bit the [inaudible] area and tried without success to get students or other people to see these as roles that some people are allowed to play in some area of life but they're not generic, you know, have some person who is the personal influential. It didn't work. I tried...

POOLEY: Why didn't it work?

WRIGHT: I tried with Muriel Cantor out in UCLA, where I said, Look, there aren't just people who influence others, or others who are being influenced. There are people who just avoid the whole area, and I got that idea from Manny [Morris] Rosenberg's paper. He wrote a paper - I forget what journal that appeared in - back in the mid or early 1950s on politics as a game, and it made a point that a lot of people are just spectators but not at all interested in getting involved in it. And I thought, Yeah, there are people who just aren't interested in politics, they don't talk around about it, they don't pay any attention, and the same thing is probably true with every other subject that we're all trying to study: food, cooking, maybe religion - these are taboo topics for many people, especially if you happen to be thrown in with the people who think the opposite from you. You don't talk about it, you avoid it. Merton did an interesting paper, you probably know it, on housing projects and whether people made friends disproportionately large or small in number. In his case he was looking at race: Did different kinds of architecture impede or encourage friendships amongst blacks and whites. That was the big mixture back in the late 40s early 50s. Housing projects were being made and that, it was, there was political pressure to make them diverse and so forth. He looked at two projects, one that had achieved this by sort of random assignment, so people ended up with people of a different race living around them - and the other was where they thought they were achieving diversity by putting people on separate floors [laughs]. You had a white floor, a black floor [laughs]. That didn't work so hot in terms of friendships forming or something because, they weren't next-door neighbors. They were something else. He worked out mathematically what proportion would be ... whether interracial friendships were greater in number than what you would have gotten probability wise just by the distribution of people in the projects, and he called it - I don't know how to say it because I get the words mixed up, but he put names on it - one was called homophily, and one was called heterophily. [80 MINUTES] And, I've read 
authors who've gotten them backwards [laughs] and that didn't help very much, but that's life. Anyhow, how did we go down that path?

POOLEY: Well, it's very relevant in part because I'm wondering about the thoughts you have about the revival, I guess you could say, of a certain kind of functionalism in the uses and gratifications approach that itself had roots, I guess, in the 1930s, with Herta Herzog, but which Elihu Katz and Jay Blumler revived in the early 1970s and it was a kind of functionalism. I noticed you wrote a paper for their edited volume - they had a collection, maybe in 1974, and you assessed this revived functionalism, and I thought you might ... I just was wondering if you could say something about your thoughts on that influential research stream?

WRIGHT: I have high regards for Elihu's work and Jay Blumler's work too. I don't remember what I said in that paper ... I somehow have the feeling that they were using the word in a different way, I'm not sure. I wouldn't want to be quoted on that.

POOLEY: As I remember, re-reading that piece recently, you were talking about how the social or system level of analysis wasn't captured in the uses and gratifications approach - that it focused mostly on individuals' wants and gratifications.

WRIGHT: It's escaped me now, I'm sorry.

POOLEY: No problem at all. And I wondered, given that you wrote a second and then a third edition in the 60s and in the 70s, there was such a backlash, at least within sociology, against Parsons' brand of functionalism - you know, structural-functionalism. There were criticisms of Parsons in particular as being conservative or focused on stability to the exclusion of change. You know that Lockwood critique and there were others, Dennis Wrong, the idea - the oversocialized concept of man. I wonder if any of that sort of ferment around functionalism had any impact on your teaching or your research?

WRIGHT: No, I'm sorry it didn't reach me.

POOLEY: It wasn't really focused on Merton and his approach anyway. It was more on kind of a high-altitude Talcott Parsons. So I was curious about the sociology department at UCLA. When you were opting where to go, you mentioned that Berkeley was a possibility in its journalism school but that you chose UCLA's sociology program.

WRIGHT: Yeah, Professor Merton said to me, Whatever you do, make sure that you have access to graduate sociology students, even if the school's called journalism or whatever. But he said, I 
don't know what's going on at Berkeley but I have a friend in Los Angeles. Call him, tell him I said to give you any information on what's going on. So I called UCLA and spoke with the chair and said l'd like to know what kind of arrangement they have up at Berkeley. Would I have sociology students or have you heard anything or whatever? He said, Well Berkeley's a good journalism school but why don't you come here to UCLA? We have an opening in sociology and anthropology. So I said - I jumped at it. And you can imagine the pay scale in California was very attractive. [85 MINUTES] I had been doing two jobs in New York to pay the rent and keep coin. Now I could go and take one job in California, which was fine, and I did. The chair was Leonard Broom, whose work I knew and I liked him and that was no problem. They had Ralph Turner and, oh God, Donald Cressey in criminology. They had [Eshref] Shevsky - I've forgotten his first name. They had [inaudible], who had gotten pregnant that semester and that's why I was gonna teach demography! Oh whatever. Oh, they had hired another young fellow, Raymond Murphy, and I can't remember the others - oh Councill Taylor, I don't know whether he was ... he was an anthropologist. They had this thing, this distinguished group of anthropologists. They had Ralph Beals, Harry Hoijer, oh, I've forgotten the name of the archaeologist - this young fellow who was alright. It was a good department. Alright to handle two disciplines at that time. Later it grew, we got about 20 members and decided to split then between anthropology and sociology, which was a good decision. I can't remember the other colleagues that I had.

POOLEY: Was there anyone in those early years or even through the 1960s in the department that you spoke with a lot or considered an intellectual friend? I mean, you mentioned Muriel Cantor and I know that was later, but was there anyone in the department in sociology or anthropology who you considered kind of a close colleague?

WRIGHT: No, there were social friends ... Joe [inaudible] was a friend of mine, but nobody in ... and Ray Murphy and I were friends. But no, I don't think any outstanding ones ... Wendell Bell was there at the time. He's up at Yale now, retired, I think. Who else, who else? Those were our stars.

POOLEY: And there was a project you were working on with Herbert Hyman and the first publication of it was in 1958 and it was about voluntary association membership. I think you two did a reanalysis of someone else's data?

WRIGHT: Those were two journal articles we wrote, yeah. Herb was big on secondary analysis. I wish he were alive today to give his reaction to big data. We didn't have the data and when we manufactured the necessary piles of data for our analysis on the impact of education on later life and then with them ... these were the days when printouts came by reams of paper, so we 
had - I don't know how many - boxes of all these data from public opinion surveys in the U.S. for the previous, I'm not sure, 20 or 30 years. [90 MINUTES] What we wanted to analyze, we had to code around these big cartons of data. Now you put it all on the computer - it' $d$ be alright, it's no problem: You get a computer record and play it. But we had that, and we arranged to work together for a month or so on a little island off the coast of Italy, tiny little island. The only way you could get to the island was to take a rowboat, and the only way you could get a rowboat was to hire a fisherman. So, we hired a fisherman, in his little rowboat to tote these reams of paper, my god! We were crazy, but we had all the data that we needed there and we went to work on it. That was ... [phone rings] Anyhow, that was on the lighter side of the work that we did. Oh. I lost something. Anyhow, what got lost in our interview so far was the fact that unconsciously - but with hindsight now I can see it - unconsciously, I used a big chunk of my life to learn something, and to learn something that would be useful in training students or just advising them or whatever. Let me just give you a little story. Back in those days at Columbia, we had evening seminars of very lively very mixed sort, mainly dealing with methodology but other things. Paul Lazarsfeld ran the seminar. I believe Ernest Nagel was a member of the seminar, and Nagel was very interested in what we were doing and he and Lazarsfeld wrote a paper on the logic of analysis, and some other luminaries. And I was in the seminar because Lazarsfeld wanted me to be the secretary of the seminar and take notes and see what happened, but I had to take my turn to do something. So I had this set of data - I've forgotten where they came from - Elmira? Or they came from Sandusky? Whatever - but they were political data and voting data and communication data, and my turn came with all these luminaries there and a graduate student - you're scared to death on that stage. But I had done my analysis, run the data, felt I was solid there. I just had to get over the stage fright of having people like Nagel and others listening to what I, poor little student from South Jersey, had to say. So, I get up to the board and I start putting up the numbers - whatever we were doing, I don't know what it was - and I had the numbers for men and I had them for women, and Lazarsfeld stops me. He says, Wait. He says, Why'd you do that? Why did I do it? Everything I read always separated the men from the women ... and I said, That's the way you always do it. He says, no, no, no. [95 MINUTES] Why did you do that? I said, That's the way it's done. No, no, no, no. He says, Well, go ahead. Give your paper tonight, tomorrow you'll do it right. [laughs] I was about to die, my professor and he's just wringing me out there to dry, but I did it, and presented the paper and it was alright. He kept it fine; it took me at least 30 years to know what he was saying. He was asking me, Why did you do that? What theoretical idea did you have? What hypothesis? Why did you do it? You don't just do it because someone else did it. You have to have a reason. It took me all that time to realize that's what he was asking me, and how clever he was not to leave me hanging out there to dry, and I must have been a big disappointment to him, but I went back and I did it right the next time and I thought, That's, that's interesting. Why would he do, why would he not just say to me, what is your theory? He 
wanted me to realize you had to have a reason for doing any kind of analysis. You don't just run the number through like a dope. And I remembered that when I taught students. I'd ask them, Why do you start out on race, why do you want to start out on sex, why do you wanna start out on anything you do? It could be lots of reasons. It could be only a grand Parsonian theory that comes down to this. It could be that you're just fishing around, so that after the fact you can say, look we got a correlation between $X$ and $Y$. Not good enough. You should have some reason for what you're doing, I believed. And I think that's what he was ... but he wanted me to come to that insight. Right then and there. I didn't, couldn't do it. But I realize it was for my own good. l'd a spent thousands of hours running things because that's the way we did it - no good.

POOLEY: I love that story and I wondered, thinking about work you were doing after Lazarsfeld in this 1950s to early 1960s UCLA period, and there was a book, that I have now looked at that I had never heard of before ...

WRIGHT: Public Leadership.

POOLEY: Public Leadership, published in 1961. And I wanted you to just give me a bit of background on where it came from.

WRIGHT: Wendell Bell was talking with somebody, I don't know who it was, important, had some connection with a publishing company or whatever, and he was saying that we had so much research on public leadership. [inaudible] They encouraged him and he got a contract and he asked, Wendell, Dick Hill, to be one of the team to get out this book, and me to do my part on it. We all had sort of overall responses we could give to [inaudible]. Basically my contribution was, I don't remember now, was one or two chapters on public leadership and that ... . Then I read the rest that was mainly written by Dick Hill and by Wendell and, it's outdated now obviously. [100 MINUTES] We thought we were telling the world something when we said we never had a woman president but, it's still true today. [laughs] My part was the communication part of that book. Dick Hill went on to be a sociologist at Texas and then up in Oregon. In Oregon they liked him so much they made him provost [laughs] of the university. I saw him at a sociology conference later and I said, Dick, what made you succumb to being a provost? And he said, well, I thought I had some ideas and I thought I could really put them to work if I was a provost. But, he said, I was wrong, because what the provost does is put out fires every day. And he said, I never had time to make my own fires. [laughs] Oh, bless him. He was a neat guy and a good sociologist - not very terribly famous but he did good work, he had been in - he got his degree from Washington, University of Washington, where he had studied sociology. But there was communication mixed in with it too. He'd been involved with some project 
where they dumped leaflets out of an airplane to see whether the population paid any attention to it ... I didn't follow the whole project, but he had that one foot in the communication area, public opinion. He's dead now, Dick is, rest in peace.

POOLEY: There was another really interesting project you did in the early 1960s and it was, it seems like, commissioned by the AAPOR [American Association for Public Opinion Research] on the use of commercial surveys. You were sort of tasked with, it sounded like, and you published it eventually in the Public Opinion Quarterly, but that must have been a politically delicate task given AAPOR's membership, its mix of commercial and academic survey researchers, and it was a very tactful publication in $P O Q$.

WRIGHT: Yeah, it was very frustrating but it wasn't nasty or anything like that. These were people who, themselves were social scientists of some sorts. Some of them had worked at the Bureau [of Applied Social Research] and whatever it might be ... and what I did was I kept running my head up against a stone wall. They wanted to help but they, their job wouldn't let them help, because it was proprietary and, I assume, had its effect on the income of the sponsors. This was not up for grabs, so I thought, What am I gonna do? I've said I am gonna write a paper, and I can't deliver. Because I can't get the stuff that we need. So I said, well I [inaudible] the problem and I wrote the paper, not angry at anybody or anything like that. I wasn't revealing a scandal or anything, I just ... the commercial world and the academic world didn't always connect together. I was disappointed but I was glad to be able to get my argument out into the field. So, that's interesting because, as a graduate from Columbia I ... when I started looking for jobs, I looked in the commercial field as well as the academic field. I was not comfortable, but ... accept for not doing the lacrosse team, I had alright relations with the academic people and we ... that was fairer play there. [105 MINUTES] And the other one too, the commercial people. They were friendly and they would like to help, and they did help as much as they could. I understood that. But then I thought, I would be bound by the same sorts of conditions and rules if I had gone the commercial way. I was glad I picked academia where you could publish anything except slanderous stuff or whether. Yeah.

POOLEY: I wanted to ask you about the 1963 semester I think you spent down in Chile. Was that in Santiago? And what brought you down there and was it a good experience?

WRIGHT: I'm glad you brought that up because that represented one of the major learning experiences in my life, and changed my life. I went down partly because of the influence of two people who were getting their degrees at UCLA at the time. I taught what was like the undergraduate level of my communication course, and I taught a course, I think I taught down there on survey research but don't hold me to it. I may have gotten it mixed up. I arrived there 
at the Catholic university, within which there was a program called the School of Sociology, "Escuela de Sociology" in Spanish and I thought, what am I doing here, why did they ask me down here? I don't speak Spanish, how am I gonna teach these people? So I said, I'm happy to come down here, I'm happy to be here, but I don't speak Spanish, I can't lecture in Spanish. They said, Oh no, no. We don't want you to lecture in Spanish, we want you to lecture in English because a lot of our students wanna come up to the U.S. and do their graduate work there. They need to hear things said in English, with your accent and all your slurring of words and everything. Bring it all [laughs] and come over! So that was very good, and I - the School of Sociology was five years long. So they had a fifth year that we didn't ordinarily have and that in my judgement was probably equivalent to the first year of graduate work [inaudible]. So I gave my course down there and I was ... I wanted to give them the experience speaking English before I wanted to give them to experience speaking English before a group of people so, I cut the lecture shorter and shorter and began to have little conversations. And I went through this semester having taught a course, at least, to the first year, second year, third year, fourth year, and fifth year people! Though, sometimes was the same course and sometimes it was different. Didn't matter. When we were ready to leave, come back - take a little trip around South America and come back to Los Angeles. Now, the students wanted to give us a send off. So, the first-year students and the second-year students combined, bought us a record. It was folk songs from Chile, South America. That was nice! That was very good. The third-year students and the fourth-year students had a little tea party, invited my wife, and that was nice. The fifthyear students had a regular party [laughs] with alcohol and everything! [110 MINUTES] It's alright. They were a little older and they were happy ... And my wife said to me afterwards, You know what they said to me - to her? I said, No, what'd they say to you? They said, Thank you for sending your husband down here. We were terrified. We'd never spoken English in a classroom before, and we were so afraid he would make fun of us because of our language, but he didn't make fun of us, and he listened to what we were saying. Now we feel much better. Now we can go any place; we could understand things. And then I realized what was going on. There was a functionary in the school - I don't know what his title was - but he was European descent - that's alright. He had told them, You people are gonna have to shape up, the North Americaner is coming down here and he'll make you shape up! So they were thinking Simon Legree was about to come in the room. I'm glad I didn't behave like Simon Legree. I carried that away and thought about it, and that changed my approach to teaching quite a bit. And, as I've said earlier in the interview, the longer I taught the more I listened to students and discussed things with them in ways they could understand, and, I thought, That's progress. I had been invited to a dinner - some kind of commemorative dinner of some sort - held in a public building like the Union Club in Philadelphia-type thing, and the dinner was supposed to be eight o'clock I think - about then. But I knew that the norms in that community were that you eat later, partly because they take a break at lunchtime and not go back to work until maybe five 
o'clock or four o'clock, because the heat of the day was oppressive. Those norms were probably formed before air conditioning, but they stayed the way tradition does. But you always figured you'd go a little later than [laughs] ... so I get down there maybe ten minutes before the affair was gonna start. I knew l'd be too early, but I didn't want to be embarrassingly late, so I made my best guess at it. There was only one person there, that was this functionary, and he says, These people, they never on time! I said, Well, if you know they're never on time, come later yourself! But he was alright. They gotta learn. It's their country, it's their way. I had to learn for ... He says, Come, l'll show you some pictures! So there were pictures along the wall of this club or whatever it was we were in. And he says, Look, look, look. Ah, there. See those soldiers? They are about sixteen, seventeen, just the right age for soldiers. I'm standing here [laughs] And he goes on about time. Then he says, I think I'm getting married in May. That is the right age to be married - the right time - I will get married in May. [laughs] [115 MINUTES] I thought, Good grief, this guy's got his life [laughs] ironed out by the day, by the hour, by the minute. And he was the one who was surprising my students by telling them that the villain was coming down.

POOLEY: But it sounded like a really profoundly important time, that it changed your teaching, and your attitude.

WRIGHT: Yes, it did. There were a couple of things involved. One, I figured, Catholic university in South America? I'm a Protestant. What kind of problems am I gonna have trying to teach sociology to ... not a single problem. It was hands off, you're in charge. That's that. Then I got thinking about Catholic universities in the States. They're probably very similar. But when I was here I never gave that a thought. I just assumed you were limited by what you could do in places like Villanova or St. Joe's. You're not limited. I mean there are probably some things that are taboo, but they would be taboo anyhow. One of the things I frequently would say to new graduate students when they'd come for advice and so forth, and they were wanting to study something sociological about religion, and I said, That's OK, but don't trash a religion now, you'll need it. [laughs] And I never took a study or a paper that trashed somebody's religion. That's my quirk, but I felt that way about it. So, that changed and also the openness to the students changed. Not that one experience alone but thread going through my way of doing things. I don't think you see anything that Herb did or that I did that trashed his, the Hebrew religion or the Christian or the Catholic, the Protestants. It didn't matter. I don't know about ISIS. I wouldn't say that I identify with, not encourage people to follow that. It's more a political movement anyhow, I think.

POOLEY: Well, you know, I think it's a good moment for us to wrap up today, because we've got through to your time at UCLA. We can wrap up with that in our next session, and talk about the 
NSF [National Science Foundation] and then the decision to go to Annenberg, when we pick up next time.

\section{END OF SESSION TWO}




\section{Transcript of interview conducted July 27, 2016, with CHARLES R. WRIGHT}

Haverford, PA

Interviewed by Jefferson Pooley

POOLEY: This is day three of an oral history interview of Charles R. Wright conducted by Jefferson Pooley in Dr. Wright's home in Haverford, Pennsylvania. The interview is part of the Oral History Project of the Annenberg Library Archives of the Annenberg School for Communication at the University of Pennsylvania. The date is July 27, 2016.

WRIGHT: Yeah, well, one of the afterthoughts that I had, that was, I think a slight handed my use of functional analysis. I don't want to put it down - I didn't... It turns out that it has been useful for me - you know, organizing thoughts. And that would apply not just to Communication but a lot of things: new developments, new inventions, whatever it might be, because that little framework that I laid out in the beginning leaves spaces that you can put in things that are - that you think are functional, dysfunctional - the whole business that I tried to stretch out into a paradigm in the early work, and I think it still does. It's not much use if you're gonna use it for testing hypotheses, but it's very good for making you call attention to both the negative effects of the kind of items or processes that you're looking at, as well as the positive ones. For example, when Herb and I were doing the study for Encampment, where we had the young people before and after they'd had the exposure to this program that the Society [for Ethical Culture] was conducting. We thought - we spent a lot of time with the directors and the people involved in the program to see what they thought they were doing with the program and the goals that they had set out and the like, but naturally people don't automatically think of the negative effects that they might have, and hadn't, intended to happen. So Herb and I thought about it ourselves, but we also looked into the literature to see what kind of possible negative consequences it could be, of this - of organized program of that type, and the best example we could find was Henry Riecken study of ... I wonder if I got the names right, but he had done a similar type study, but different from ours, but he had looked to see whether there were negative effects or potentially negative effects. We wrote to Hank and he was generous, allowed us to modify his - some of his questions a bit to fit our program, and that was very helpful to us. The same thing could be used for example, when people are talking blue-sky-wonders of the digital age, and there's negative effects possibly there too. Now, we were not - I wasn't at least - in any way interested in trivial positive or negative effects. In my functional analysis thing, I was very careful to point out that Merton's theory - he focused on 
what had become taken-for-granted types of requirements or whatever the components might be of the program. So - but I never wrote all that out all the time. [laughs] You plant the seed and you hope that it will grow, and people will use their own backgrounds, theories, and so forth to fill in the expected or unexpected consequences that, that whatever it is they were studying-whether it was a program or a process of working or however-might have either positive or negative consequences. One thing I left out - I think I left out - I didn't go back talk to look this up at any chance, [5 MINUTES] but I think I left out the term for behaviors or actions that had no significant function or dysfunction or so I could [inaudible]. Otherwise you would be sitting around playing with trivia for ever and ever because things are interlinked. So there's a lot of qualitative judgement and opinion built into this scheme that I laid out, and I didn't so much drop it as internalized it, and used it, [laughs] and put it that way. But when you'd asked me what to elaborate, I think I'd given the back of the hand to it but I shouldn't have done that. That's important. I do wanna make that clear.

POOLEY: Can I jump in with a question as a follow up to that, which is: You already, in the book and in one of our earlier sessions, noted that Merton and his brand of functionalism was very important for the book. What about the broader Bureau of Applied Social Research findings on media? I'm thinking of Joseph Klapper and his dissertation that summarized the media effects research at Columbia, and then the book he published close to the time when you published yours, that was called The Effects of Mass Communication, which has had as its punch line that media tend to reinforce beliefs. That was the overriding theme I think, and I'm just wondering if that kind of Klapper line of reinforcement had anything to do with your own thinking about media and its functions for society.

WRIGHT: No, well, Joe and his work was a little bit ahead of mine. We all knew what he had done in the book, all [laughs] fellow [inaudible] or whatever you were gonna say, but I didn't use that as a point to start or refer to it or that. It was another thing that students wanted to know about, read about. Yeah, but I was influenced directly by working with Merton and Herb Hyman, and Lazarsfeld of course. It was the first-year, first-term graduate student who in the department had a party welcoming new students, that kind of thing, and various faculty members said a few words. I remember Lazarsfeld stood up and he said he had new interests. He says, And here comes Charlie Wright to study communication with me, and it's not my main focus anymore. [laughs] I said, Imagine you're a graduate student and you hear that, [makes choking sound; laughs] What have I done? But he underestimated the amount of attention that his work and he would get in the communication field. There was no communication field at that time. It was - you could see the seedlings: Wilbur Schramm was doing what he did and I forget what - [Claude] Shannon and [Warren] Weaver were taking things in a different direction, but there ... Schools were just being established, and as we mentioned last time, 
many of the traditional schools were doing journalism-type work, and that's good if you wanted to do that - that was very good. Columbia didn't - had its own school of journalism which was, touched base with the sociology thing but was primarily its own school. I can't say about other universities because as a student l'd just hear about it and I'd know. But the reason I one reason I stayed at Columbia was that I was interested in other things in addition to communication. It's very funny the way areas of interest struggle to get academic credit [10 MINUTES] - credentials - and that, I think, was going on at a lot of places at that time. You had also, a lot of first-rate brains coming back into the field after having had experience in the military with communication problems or programs or whatever it might be, and they took their particular style of research with them when they were able to set up programs at different schools - like Carl Hovland up at Yale, and others that you know about, I'm sure. But the Columbia one was very diverse, it had practical implications for the military and civilian problems during World War II, but basically they brought field research into the forefront, I think, rather than laboratory-type experiments, which Hovland was doing up at his place, and that excited me and interested me very much. I've forgotten the different places that they you had to classify what you did, and I looked for some reference to communication, but sociology was solid in the there so was psych - but took a long time before you began to see that as a box that could be checked. Somebody was doing communication research, what's that? [laughs] We found out what it was, and it's continued to change - that's exciting too. If I were starting out now I think I could not absorb the amount of published material that I did absorb as a graduate student. The field has grown so big now, you got stuff in neuroscience, you got this, you got that. It's fantastic - very exciting.

POOLEY: Since you brought up the topic of sociology and communication research establishing itself, I wondered if you had experienced, ether at UCLA or Annenberg, the claim that's made by Elihu Katz and others that - and you, in fact, in a piece you wrote in 1986 - that American sociology had, somewhat at least, abandoned the study of communication research, maybe in the 1960's, and this is a claim you hear from time to time. What do you think of that argument that sociology, in the U.S. at least, abandoned communication research?

WRIGHT: I don't know. I don't remember reading that comment any place. Certainly I don't think Elihu abandoned it, he continued to do work ...

POOLEY: Well, he said that people who were sociologists who got - who remained interested - got hired by communication programs and schools, like himself, like you.

WRIGHT: Yeah, well, I think that's probably true. The Langs [Kurt and Gladys], I think he - one of them took a sociology post, the other one took a communication post - Kurt took the 
communication post. Elihu and I [inaudible] went in and out of departments, but he stayed basically with sociology, and so did I in my research. So I don't know what to make of that comment. I think it certainly must have looked like that for young people who were looking for jobs, [laughs] but they were hiring in sociology. They were hiring some people who had, at least as one of their specialties, communication. Again, I haven't researched this myself but I do recall various points in the history of academia - let's call it that - you would find that communication and public opinion linked, or some other kind of link that would carry communication with them or it would carry there, but I don't know which. [15 MINUTES] Now it became globalization, and put that word in with communication and you're OK. I guess the technical side has excited people and prevailed, and the globalization - as we mentioned. There was always a little bit of it, but for many years it was basically American study, American communication systems, and some studied other ones abroad. The Bureau [of Applied Social Research] did a series of studies back in the late 1940s, early 50s on the Middle East. Communication - and the very same countries that they're working on nowadays. They did stuff on that back there.

POOLEY: Yeah, I wonder if Daniel ...

WRIGHT: ... there was interest in Africa and all. It was there but it wasn't called globalization at that time - and globalization means somewhat more than just studying particular individual countries. You asked about Columbia again, we've talked - well, we've we seen the work of Lazarsfeld that's there, and Merton's work on Kate Smith and things of that sort. And Herb Hyman was very heavy on survey-type research - national and international - and did a lot of work with and NORC, National Opinion Research Corporation, or Center, pardon me. But we also had on the faculty Dan Lerner who taught Psych War, and that reached out and began to shift over towards development of countries and their different viewpoints on it, I guess. But I do remember one early point in the stage, when they were - there was talk about how do you bring countries that had not really independently grown in production and other forms of commerce, and in government, and there were other things. Because there was thought to be a shortage of teachers in those areas and for a while the argument was made that radio would be a direct and fast way to bring whole generations up to more formal schooling than they had. They didn't have enough teachers around, they thought, to do it. This would give it a big boost. And there was research on the effects of these programs too.

POOLEY: Daniel Lerner himself didn't he write up some of that Bureau research on the Middle East in that The Passing of Traditional Society book? I don't know if that was ever in the air at the Bureau - that work on the Middle East, and Daniel Lerner's ongoing interest in modernization? 
WRIGHT: Yeah, I'm not following you, I'm sorry.

POOLEY: Oh, well, I just wondered if in the Psych War class or otherwise, if this work on modernization in the Middle East, if it was discussed a lot at Columbia?

WRIGHT: Well, maybe in some of the seminars - not in any that I took. But l'd say, yes, it probably was there with Lerner spark-plugging some of that. There were other people involved too, and I just can't think of any off hand.

POOLEY: You did want to mention other graduate students at Columbia that you had connections with or friendships with?

WRIGHT: Oh, yeah. Well, I became good friends with some people that I had known before. [20 MINUTES] Robert Williams was at Columbia College as well as graduate work, and we were friends, and he was bent towards psychology, and I was bent towards sociology. [laughs] So we didn't have much common experience on the courses, but we did take a few - we took a seminar with Herb Hyman and that's where we got the idea for the paper that we did, which is long, long gone. [laughs] I couldn't even find a copy. [laughs]

POOLEY: I have one if you ...

WRIGHT: It's lost out there - I beg your pardon?

POOLEY: I have a copy.

WRIGHT: Oh, you have a copy? Thank you. It lives! You've still got a copy. Bob's gone. He died a few years ago, and we never went any further. He did go further himself with it. He made that become his focus for his dissertation in psychology. But, then, personally ... and he taught psychology with some communication stuff in it I'm sure, but I didn't look at his courses so I wasn't sure what he did. But he didn't - he wasn't happy with academia, and he went into marketing-type research - of which there was a demand back then. Still is. Several of my students have gone into the "industry," as they call it, and they do very well. I'd say at least two of them that I know went into measuring the audiences for news on television and radio - that sort of thing - which makes sense. You could see how that would be of interest to communication people, and the like. [phone sounds] Please. Thank you. [phone sounds again] Oh, I'm sorry Jeff. 
POOLEY: No it's OK, let's just wait until she hangs up if that's OK, and I will cut this part out. No trouble whatsoever. But just while we're off camera - it's still recording, but I'm gonna cut this out - but if you want to mention the other Columbia graduate students that you had written to me about, you know, you ... don't do it yet. Let's wait until the phone call is off, but I just wanted to prompt you about that, because I can always include a footnote but it would be better if you spoke about it, you know.

WRIGHT: OK, are we back? Oh, we're back, OK. Well, I think I had mentioned earlier, there was at Columbia, at the same time that I was there, a great interest in professionalization and a particular interest in medical areas. George Reader was from Cornell University or their medical school in New York. I've forgotten the name now; they've changed it recently. And that school was - that medical school - was beginning to experiment with an approach to medicine that took into account the whole person not just his or her kidneys or heart, but other environmental [inaudible] ... their family set up, work problems - whatever they had. Looking at the whole person and their - now they would call it all of their networks I guess. But we didn't use that then - that sort of thing. They came to the Bureau for help and advice and performance evaluation of their progress, and another graduate student, Mary Goss was ... went to work with Reader in the hospital there, and she stayed there, and was one of the early - what we now call medical sociologists - and was very successful at that. [25 MINUTES] So George and she and I were friends and later Mary's husband joined our group, and we'd go to conventions together - things like that. So that was a close connection, and got me a little interested in medical, the growing field of medical sociology. Pat Kendall did some of that too - and others at Columbia, and that was good. Bob Williams, I mentioned, was a friend who then went on the psychology bent, not sociology. I don't know who else I mentioned or have forgotten, to tell you the truth. I don't know. It was a friendly group at Columbia but my tendency was to do my own thing, and I did that. It's very hard to trace back what influences you - or did influence you - and all that. Makes me nostalgic [laughs] just talking about it.

POOLEY: Yes. Well ...

WRIGHT: I did more - I didn't do much collaboration except with Herb, except with a couple of my own students later on like Muriel Cantor out at UCLA. She was not just a student - became a friend of Ann Marie's and mine, and her husband became our friend too. He was an interesting fellow - a psychologist. After he retired, he became an anthropologist. That's an interesting combination. But he got interested in the same communication areas as his wife Muriel did and they wrote several books later on that. Her dissertation became a book - was on the producers of television evening dramas. I don't know if you wanna use anecdotes or not, but I remember full well she'd been my assistant at UCLA for a couple of years and I really had a 
project I wanted her to work on, but she didn't - she wasn't really very interested in doing that. The project I wanted her - didn't - never got to be solid research but the idea that I was playing with was that opinion leaders were more likely - some of them at least - more likely to be playing a role, that was, somehow they got cast into rather than that there was a dynamic, gregarious person that would get it all, but I didn't develop it. I wrote about it a little in the book but didn't follow up. So her dissertation had to do with producers and their role what we now would call the role set: directors, actors, writers. And her focus was, what in particular did these role interactions have to do with the final content that came out in this stuff at night? She said, I look occasionally at the evening stuff and it's not very exciting or very good or even just strange, and I look around at my neighbors-she lived in Brentwood-she said, They're bright, intelligent people. I wonder why are they turning this stuff out? That's what she started to study it, and then it grew from that into a more interesting thing now. I remember I mentioned in the first interview we had that I've always tried to put things in clear, simpler language and not necessarily dress it up with jargon. [30 MINUTES] I don't think she ever uses the term "role set" but that's what she's working with, and wouldn't gain anything by naming it then. Did a lot by describing what was going on. So it - and as I said that became a nice friendship that we had. I miss her and I missed her husband both - they're both gone now. But she stuck with it, she became chair of sociology out in Washington. What's the name of that college there? It's slipping me - nice little school out in Washington, DC. Anyhow, so she stayed in sociology, didn't go into communication - she studied communication, but didn't go and do it.

POOLEY: SO ...

WRIGHT: And then here at Penn I also did some collaboration with Jo Holz, who this past year or so been back at Penn working in the Kathleen [Hall] Jamieson shop next to us [the Annenberg Public Policy Center]. Had a great student Hannah Kliger-the last I heard she was with Penn State Abington. But she didn't study the ... they all - they were all doing communication stuff, but hers turned out to be focused on interpersonal rather than mass media, but some mass media. What she was studying with was the history of voluntary associations of immigrant groups in the U.S. in the - from the early twentieth century until she did her dissertation. And that included then the foreign language papers that their group made and distributed and helped to keep together as a community. And there were a few other students of that type who were exceptionally good, I thought, and I enjoyed working with them. I enjoyed working with all of my graduate students. It was always fun to see somebody have an idea of their own, and nourish it, and make it grow, and bring in some sociological concepts even if they didn't spell it out. You could tell they were thinking that way, and that's why I came to Penn - which we will cover next time if you're here or later today, whatever 
your plan is on that. So - but again, my social life - it wasn't built around the university or student activities. A little more so at UCLA, maybe, because it was Hollywood. [laughs] Whatever we did was fun.

POOLEY: Well, can I ask about UCLA? I have two related questions, one of which is about Ralph Turner and his role. I saw you wrote about that experience, and the other is about your role as the head of the graduate research training program. It looked like in the period from 1963 to 1967 you were in charge of the graduation research training program, and that may have been significant - it may not have been - but I was curious in part because of your dissertation at Columbia, and whether - and your discussion just now about graduate students - what that was? [35 MINUTES]

WRIGHT: I'm not sure I follow the train of it all there. When I went to UCLA it was a joint department: sociology and anthropology. Shortly before or maybe a little after - it was tough in time to distinguish it-the department split, and sociology went one way and anthropology another. It was, I thought, a very interesting and very exciting department to be in; it was my first real job, not counting the Columbia experience, which was real enough but I was teaching in my own school in New York at Columbia and [inaudible] feel different when you start a new job across the continent [laughs] and you don't know a soul to begin with. I think I told you that the chairman had handed me three different courses to teach than I had originally talked about giving. Eventually I got my own package in but I had to put in my time as the young boy on the block [laughs] and fill in for somebody who was sick or ill or on sabbatical, or whatever it was. I don't think we had - or I had - much formal influence from the anthropologists. I knew a few, I knew [inaudible] very well. His specialty was blood-types. Anthropologists studied bloodtypes? That's what he did, he went to Australia I think. Well, anyhow, I talk with him a lot. Ralph Turner was a good friend. He was trained at Chicago, and despite that he was [laughs] a good fellow, but didn't do much on communication. Nobody did that, except for some people in journalism. Jack Lyle in Journalism was a good friend of mine, he worked with Wilbur Schramm on several projects, and Jack also headed some extension program they had in Hawaii - l've forgotten the name of it. The connection here is that after I had been at UCLA for, I don't know, four - about five or six years, maybe a little bit longer-several of us came to the same observation and conclusion that we needed to have a research institute of some sort that would provide the opportunity for our students to put into practice some of the methodology we were teaching. Oh, I lost my glass of water. Oh, here it is, excuse me-throat's getting dry. And we formed a committee. I can't remember all of the people involved. One was Leo Reader, who was a very prominent medical sociologist, one was Jack from journalism, and the chair of journalism, Walter Wilcox, myself, I think somebody from political science, but I can't remember who it was, and several people from journalism - Jack and Wilcox, being only two 
of them. But we came up with a plan to have a very modest research institute, mainly surveytype research but other things possible. And we were careful - worked it out, [40 MINUTES] and we figured it could be done on " $X$ " number of dollars, and we trotted off to the administration and presented our plan. It would have cost $\$ 30,000$. [gasps] In those days that was considered outrageous. [laughs] OK, so we didn't get it - it didn't come through. But we didn't quit. We had a couple anthropologists interested too. Our little proposal was sitting inside somebody's desk drawer and [laughs] that was the end of it. We came to the ... I wouldn't say conclusion. That makes it sound too final, but amongst us the idea came up that we ought to split the things up an organization might do, and try to get them funded somehow, inside or outside or whatever. And so we did that: we got a grant for training, and then a research part. Well, people splintered off and did, but the availability was getting better as years or so went by and finally the UCLA unit was approved through the School of Public Health, and Leo Reader was in charge of it. And they couldn't have picked a better person. He was a good man, and knew his research and knew his medical stuff, so that worked - that was a good move - and we ... some of the others of us, including Ralph, applied for a training grant and got that. And I directed that for a while, and I thought it was a successful program in getting people to learn more about ways of social research and how they might fit into the problems of health and public health and medicine and things of that sort. I don't know how many of our people limited themselves to medicine or went primarily into it or whatever it might be, because I left UCLA in '67 - didn't leave it, I took a leave of absence to go with the National Science Foundation, and then as fate had it I didn't go back to UCLA. I came here to Penn, so I couldn't follow up any of the bright people - they were bright people - and I think they were influenced by the training program. I was certainly influenced. I was beginning to learn what and how you can teach things, and I got not a very original idea but nevertheless I got it and tried it. I set up a seminar where the students had to read a workbook or article, didn't matter, by the faculty members in sociology and some other areas if it fit. They'd read it and then in the seminar we would invite the author to come in, and students would have prepared questions like, Why did you do this, or why did you do that? And the faculty were amazingly candid about the problems, the real problems, of getting research done out in the field, and I think that sunk into the students pretty much - I hope so. We had one faculty member, I won't mention his name, but he had written a very successful book through what could loosely be called participant observation and face-to-face interviews with people [45 MINUTES] - that sort - and I said to him, Will you let the students read that and tell them the problems you had and why you decide this or that or the other? He said, Yeah, I'm willing to do that but I want tell you in advance, in my opinion good interviewers and participant observers are born and not made. [laughs] I said, Well, OK, just tell us how they were born for the study you did. Well, he did - he said ... well, first of all he took a long time to do the book, and in that sense he was more like an anthropologist than sociologist was at that stage. And he said he 
wanted to talk with the workers and all that, and he found out that what they liked to talk about most were sports, and baseball in particular. So he trained himself: he read the statistics on who threw so many pitches-this, that and the other thing. And they absorbed him into the conversation, and eventually he'd also just learn other things about the informal structure of the business, you know. The formal structure you can get. There's the president, the CEO [inaudible]. He found out how things really worked - the shortcuts that had to be taken and the like. So, I hoped that what the students heard all that it would sink in that you don't just walk in unprepared and you're gonna be swept into the arms of the - [laughs] you gotta earn your way, and respect, and the like. I remembered that. So, whenever I would hear arguments in that department or wherever about we gotta have a course in qualitative interviewing or qualitative research, I think, No, you gotta have somebody who does it, and can do it well, and can talk about how to do it. But it's - you know - it's not like ... you can write a book about how to do survey. You gain a lot of personal experience. Experience counts - Herb just knew, by instinct, many things. He could tell you but you don't learn it until you do it. So, that was a good experience for me and I thought that the sponsors got their money's worth in young talent that might become interested in public health or medical problems, and some did, I'm sure. I just didn't follow them up very much. The other thing that that training program did, I guess, was strengthen our traditional training by giving them more variety and more experiences and focusing it all more. I began to think more and more about what teaching consists of and how you ought to do it. And some of it I was able to put into practice. Some of it not. I don't know. Is that the sort of thing you wanted to hear?

POOLEY: Absolutely, and I wanna just ask about one more mid 1960 s project and this was, I think, a collaboration with Herb Hyman, and funded by the United Nations, about expert opinion, and ...

WRIGHT: Oh, yeah!

POOLEY: ... it led to a book in 1967 called Inducing Social Change.

WRIGHT: Yeah, yeah ...

POOLEY: So it came from the UN, I suppose, and if you have any thoughts about that study and working with Herb on it ... [50 MINUTES]

WRIGHT: That study was part of a trilogy that Herb was going to do, and I was gonna help him. Part one was ... well, the big problem was how can you help developing countries get more modernized, for lack of a better word. So the first part was what we published. What Herb and I 
both thought, Let's talk with people who have been doing that for a number of years, and just get them to tell us what were some of the obstacles to putting in a new well or whatever it might turn out to be. And we did that. It was a complicated and difficult survey of people who'd spent a large number of years on developing projects in different places and all of that, and it was a good study I think. Interesting and fun in some ways, but we were well into the study when some feedback would come from somebody who would send in a questionnaire six months too late or whatever, but they'd been up in some [laughs] mountain somewhere in a remote tribe and they couldn't fill it out but they told us what had happened. That was kind of fun. The second phase was going to be - now here's where my memory may distort things and I may get it wrong, so I don't want to say this is the ultimate truth. But the second part was to do comparisons of successful and unsuccessful efforts at development [inaudible]. That never got off the ground. Why? Nobody would say their project hadn't been wonderful [laughs] and successful, and so we would - just didn't get the documentation we were hoping to get. I honestly don't remember what part three was. It didn't happen because part two never happened [laughs] so whatever were we gonna do, I don't know. So part one stood on its own legs, may ... there may have been some surprises in it, maybe not, it depends on the reader. But I know that it was built on solid data. It had good data and people were frank about it. I would have thought, Well ... well, we didn't even think about part two and three until we had finished part one, anyhow. I wasn't involved in parts two or three, or what happened to them I don't know. We certainly didn't carry it further than that. Herb may have given a paper or something but I didn't. Why does that particular project tickle you or [laughs] your curiosity?

POOLEY: Well, I was in part curious about it because of the timing. It was that period when there were lots of modernization studies going on - I think of Wilbur Schramm's

Communication and National Development - and by the time you published part one, I think it was 1967, you know, that was when some of that modernization work was coming under criticism, maybe just during that period and into the early 1970's, and I didn't know if you continued on - it sounds like you didn't maintain an interest in those topics?

WRIGHT: No, no. No, we didn't. I didn't anyhow. I don't recall Herb working with anyone else on any parts of it. [55 MINUTES] I may be getting projects confused in my mind as it was so similar. I'm sorry, I should have done my homework on this and refreshed my memory. No, I don't know. Gene Levine worked on some projects with us and Terry Hopkins worked on the Encampment study. Gene, who was a friend of mine, I don't ... he was in Geneva too, so it had to be connected with the UN. Maybe he did some work - I think not, I think he may have worked on the stuff we hadn't had. I'm sorry I just don't ... 
POOLEY: No problem. So let me ask about another 1960s event, which was you moving to the National Science Foundation in Washington, taking the leave from UCLA. What motivated you to take that post, and if there were any highlights from those two years of service?

WRIGHT: I'm glad you brought that up. Yeah, what motivated me was a ... it was an important agency and therefore, wanted to be sure that they got the service that they needed, and that sounds corny but I'm patriotic. [laughs] I thought it was a good thing to do. I also thought I could personally benefit in the sense that I would be up to date on things that people wanted to do research about, and better than that I would be seeing stuff that wouldn't be coming out in publications for another half a year or year with time delay in publishing, and that was a boost, I think. And it was true - it was actually true. I learned what the future interests were, and some important projects, and I suppose, selfishly, the idea of living in Washington for a year or two was appealing. [laughs] I'll put it that way. And, strangely enough, in a nonpublishable way, I was right, because what I found was I got to know several people - a lot of people at the ... from the NSF but several other people in Washington that are often scoffed at as, oh, the pointy-headed bureaucrat and all that. No, it wasn't true. I had two advisory committees because I was handling both sociology and social psych - excellent people, people like Don Campbell and so forth. And there was no sloppy way of handling the reviews. They were good reviews of the projects proposed - very honest - and those guys on those committees had to read, eventually, hundreds of applications, and they would - we would sit, when we had our annual meeting or - it's not annual - we had our meetings, we had about three every year I think, they'd work until eight, nine o'clock at night from having started at nine in the morning. The reward would be you could - you get a dinner. [laughs] No, thanks a lot - easier way to earn a dinner! Anyway, they were good natured about it, and they worked hard and gave good tips to me about what to say to the researcher if there were some problems with their thing, and it usually - often were. So that was a personal experience. [60 MINUTES] I just cringe every time I hear a person say that, the bureaucrat's spending our money - taxpayers' money! They're not - they weren't throwing it away. They were careful about it right then. That changed my attitude. And most of them stayed there for a long time so they were ... they knew the formal and informal structure of government and what not to do and what to do to make the place work right, and it was very good. Those were, you know - I didn't even put that in writing anywhere. It didn't have anything to do with it, but I felt I lent a hand. Well, I should mention the NSF also at that time was, if not the only, one of the few government-supported agencies that took what we used to call "pure research" stuff, because it wasn't applied [inaudible] research problems that might come up from military or some other branch. We had agencies that did that. People could get grants from Defense Department or whatever thing. But you had the NSF as the place you could go and where you could simply study the problem from a theoretical, research point of view. It was very good. Got tighter as 
the budgets got shorter, and this was a place that could squeeze it a little bit, and it just changed over time up and down as everything in Washington seems to do. What's another point? Oh, yeah a second thing that I learned - I should have known in advance but I didn't there was all this quarreling going on in departments of sociology, social psych, and communication, but I didn't get very many applications for that at the time because we ... but in any case there was always fights in departments about the quantitative versus the qualitative thing - baloney. We didn't favor quantitative research over qualitative. We looked at the whole project and what it was going to do, and I think that a key question, not "the" but a key question was: can these people do it? If they' $d$ already built a record, then that was in their favor. But everybody has to get started so you were a little more lenient maybe with a new person. But it wasn't a matter of, They're qualitative - oh take them, or, They're quantitative - oh take them. Baloney - and I still hear it today! Not about NSF in particular, but the notion that you only do one type thing - it's baloney. We even mixed qualitative and quantitative research, Herb and I, in our own studies. So that was a awakening for me that, No, we're not biased in favor of this or that or against this or that. We're biased in favor of good research, good work - publications, things of that sort. Yeah.

POOLEY: So ...

WRIGHT: And I also got - from a personal point of view - a very good feeling that sociology and social psych were being represented in the agency, and that was important. They've rearranged, I'm not sure what the current structure is like. It's a little different. I think social psych, if I'm not mistaken, has been cut off and put into medical, biological, that unit - I think - less in the social unit. Sociology still stands by its guns there. I don't know about anthropology or political science, whatever. [65 MINUTES] One thing that was developing at NSF - hadn't quite gotten strong structure at that time. Now, we're talking about 1967, '68, but what was being under consideration - not by me but by another unit called "Special Projects" headed by a psychologist Murray Aborn, I think his name was - what came out to be was the big national surveys where they could change the topics each time that it was done, and when they kept some topics to have continuity through it. That was partly, I think, an effort to give social scientists the machinery that physics people would have. But now think of it, of course we gotta have a whirlicon [laughs] and it's gonna cost 10 million dollars. Oh that ... [laughs] wanna do a survey that's gonna cost a million dollars [gasps; laughs] and [inaudible]. But it works, this works - or it did work, I assume it's still working now. That - almost everyone I talked to thought that must be a nifty idea to have a commonly shared survey like that. And common sharing is a touchy point, as I found out when I tried to get my hands on some commercial research. As if I could use it commercially. I wouldn't know what to do with it. [laughs] So you like coffee ' $X$ ' better than coffee ' $Y$ '? Gee, that's nice, come on have a sample. 
No. So, that was a good experience. I also got a feel for Washington and it was nice compared to the terrible things that have happened recently with - a week ago, sitting in the park what is it called - across from the White House? Lafayette Park. Have lunch if you want, eat a sandwich, nobody bothers you. Couldn't walk into the White House, obviously not, you don't want that, but you didn't feel like you were somehow in a place that had security people in every corner. [laughs] Didn't need it then, or didn't think we needed it. I know I'm leaving out some things but I can't remember what they are. Things that I wanted to bring up in our conversation but I don't know.

POOLEY: Do you want to look at your notes? Do you want to take a look at those notes?

WRIGHT: Oh, the notes. I think we covered them in a strange way, but we did cover some. [inaudible] I've got them. Well, it's out of sequence but I know you were interested in Ralph Turner, and I don't know what I can tell you. Let's see, he represented the Chicago School, and well ... he did work on collective behavior and that brought in some communication stuff from wherever it was - was in psych or anthro or sociology? He was a gentleman, a good teacher, a good colleague, a good chair. He steered us after we split from anthropology. I liked him a lot. [70 MINUTES] He was an Anglophile. [laughs] He loved everything British! And he involved me in his study of the earthquake stuff. While I was here at Penn I was a consultant on that project. It was a good project. I don't know [inaudible] if you ever saw his book called Waiting for Disaster? Oh, what happened was the federal government got interested in - they have emergency set-ups, and some how physicists had learned a way to predict where earthquakes might be, but not with precision. They'd say, It'll be Havertown [Pennsylvania] or whatever. They were ... somebody in the government asked Ralph at UCLA, could they do a study of how people felt about the media presenting the scientific predictions about earthquakes - which they were doing. And so he decided he could do it himself and replied - wrote a proposal and they said, Yeah, go ahead. And he took this project on. Very fascinating because all the research prior to that having to do with earthquakes, and other kind of emergencies, primarily consisted of going in after the event had happened and studying how people reacted: how they saved themselves or others or their property or whatever it might be. But now we had something new, a prediction of a ... of a earthquake that could be studied and people's reactions to it. And it'd be simplified but it won't do it justice this way. To no one's surprise he found that the initial news about the prediction and so forth reached people quickly by radio and newspapers - the mass media. And he did a continuing survey several months apart, like a panel study, and it wasn't much but at the end of their time period - they studied for a couple of years, I think people were shifting and getting their information from other people more than they did in the beginning. So that, you know, fed into the ... some of the personal influence stuff or whatever it might be, and I helped a little bit on that. But, anyhow, that was a good study - I think vastly 
overlooked by ... and I used it in my graduate class, I used it at the - and they would just take a look and they'd say, Oh, 1969! [laughs] I tried, I never really quite succeeded, with some students I did, but most not. I tried to get them not to think of this not as an earthquake prediction, but disaster, as Turner called the title. What are the things around us that would predict a terrible thing happening that's gonna happen somewhere around where you live but we don't know quite where, and it's gonna be big but we don't know quite how big it's gonna be, and well, maybe it won't. Well, we think it's gonna happen but we don't know just when. I said, What have you got? You've got terrorism. Think of - try to get rid of the dating detail and think, How do people handle this kind of threatening? We had it with the atom bomb back in the 1950s. We've got it now with terrorism - whatever name you want to call it [75 MINUTES] - that's going on around there. How do you live with that? What do you do? If they say, It's an earthquake coming someplace around the Delaware Valley, I don't know quite where but it's gonna come, but, well, maybe not this year, but it's coming. People are gonna get hurt or we don't know how bad. How do you live with that? That's the study, I think. That's the problem, and they get diverted by other stuff that [inaudible]. I don't care, I haven't ... and I just have not learned how to get students to generalize and then predictorize afterwards. I don't know how to do it. I can tell them, [laughs] that that's why I put the reading on the list. They have to make the connection somehow, I think. And I've been trying to do that with other things besides terrible disasters - you know, just to get them to not worry about, Is it the newspaper, or is it - unless it's relevant, but if it's not relevant why bother with it? And now I'm gonna hang up my guns and [laughs] I never will find out how to get them to think that way. I do that with dissertations too. The original idea sometimes just doesn't click, but you can go back and say, What was I really trying to do? And I don't know how ... I'm boring you with the details [laughs] of teaching, which you know well - you're trying it yourself. You'll get new experiences and you'll change your style or your mind, and thank goodness good universities and good colleges make enough allowance - I don't think they ever spell it out, but that's the freedom in the classroom. You can fiddle around a bit and try to get people to see things. Don't we learn anything from the past? No. [laughs] Anything from the past? Just watch the current convention - the previews to the convention, some of the stuff that the candidates were saying make me shudder. Yeah, that's life.

POOLEY: Well, let me ask about Annenberg, and here you are in Washington, you're working for the National Science Foundation, thinking you'll go back to sunny Los Angeles, and yet you decide to move up to Philadelphia and go to Annenberg, and, were you invited? What were the circumstances of your appointment here?

WRIGHT: It's ... they're not quite hidden in what we've been talking about before. I thought that with a whole school devoted to the study of communication, I would - it would - attract 
more students who were interested in the same kind of thing that I was interested in. So I could truly say it was the promise of a school that was becoming more research-oriented. It started out as a more, little more performing-type thing but shifted over. Now it's almost completely research-oriented. I think that I was brought here to encourage and open the students' minds to concepts that come from sociology like role set and social structure, this, that, and the other thing. Not that they had to do that but they were to have that in their tool kit. They weren't thinking that way - I think they weren't thinking that way. So, therefore I didn't throw away my sociology. I brought it with me and there was an audience for a while. [80 MINUTES] They were forced to take some of it [laughs] but I had plenty of rigorous students who were interested. When we first came here it was strictly a graduate program. It wasn't until years later that they broadened the program to include undergraduate work, partly at the request and demand of students who were looking to the future or maybe had misconceptions of what it might be like. But they could test of it here and that worked out. It's a good quality program now, I think. We still stress the doctorate. That's our main, unique offering. So, I took my turn at teaching the undergraduate stuff too. Basically I did some of the same but presented it a little differently or I was still trying to guard myself against the jargon bit. [laughs] That worked out alright. And the students at Penn are very nice and very bright, and I can compare them favorably with the students at UCLA, and at Columbia. So, that was OK, but it was the academic program that brought me - which really sounds weird but it's true. That's the way it was.

POOLEY: Was it George Gerbner who recruited you?

WRIGHT: Oh yeah it was George. Yeah. He had tried to do that before I went to NSF. I said no, I was going to NSF, and then when my time at NSF was running out I was gonna go back to UCLA. But he did the recruiting. I had had one member of the faculty on one of my consulting committees in Washington, so I knew something about the academic program here.

POOLEY: And who was that?

WRIGHT: Percy Tannenbaum. He was going to be the chair of the graduate program, but he left to go to Berkeley to head up their Survey Research Center out there. I didn't know any others. It was a mixture, I guess, of some new people George had recruited and some folks he had inherited from the past, and he respected that, and he kept them on. So we had - Percy was there. Charlie Hoban, who had done some work in ... on the role of motion pictures in educational settings. Yeah, he was there. They had a young fellow, Larry Gross, [laughs] and he stayed until a couple of years ago when he left to go to Annenberg West, to head up their graduate program there. We had Robert [inaudible], who was in the media in different kind of ways, I guess. We had Hiram Haydn, who was the editor of a scholarly journal - I've forgotten 
the name of it now - for Phi Beta Kappa people. [Charles] Hoban. We had Sol Worth, who teamed up with somebody from Temple, and did a nifty book on what Indians do with a camera when you give them and all that. We had the man who did those prints of [85 MINUTES] ... that print over there, Sam Maitin, yeah. Al Rose who did the television production stuff, which eventually we dropped. Who have I left out? Oh, Ilona, she did the drama, Ilona Gerbner.

POOLEY: Was Klaus Krippendorff there?

WRIGHT: Oh, Klaus? Klaus was the young fellow who was here, yeah. He had come with George from Illinois, Indiana - wherever it was. Yeah, and there were a few other people. I'm just blocking the names.

POOLEY: How about Ray Birdwhistell?

WRIGHT: Ray came the same year I came, yes. He did, you know, body motion and communication.

POOLEY: The school was smaller, and what was it like as a faculty member there in 1969 - the early 1970s, that period when it was still pretty young as a school?

WRIGHT: Yeah, it was small, yeah, smaller, right. What can I say? We ran it like a little department, and continued to search to add people who would bring something useful to our students. We had for a while an economist, William Melody, his name was, from Canada. Think, think, think ... Oh, I mentioned Sam Maitin. He did the silk prints and stuff. I'm gonna look at the old books and I won't remember their names. [laughs]

POOLEY: Were you close with any particular faculty members in those early years - any friendships?

WRIGHT: Birdwhistell.

POOLEY: Birdwhistell?

WRIGHT: Yeah, we were on the same page. I mean, he was on - oh, I shouldn't say we were on the same page but we were in the same book. [laughs] He was unique, and students loved it because he would do what might sound like crazy things to you and me - or to me, not to you. [laughs] Like he'd bring something like this in the room before it was widespread, and he'd say, What's that? Describe it to me. And his students would look [inaudible], It's - looks like eight 
inches tall and it's got three legs on the bottom, and it's got a little do-hicky around there. It's black - it's painted black, and it's solid. And they'd think, Ha! There is it. And he'd look and he'd say, How's it taste? Taste? [laughs] Well, they'd taste the thing! He'd say, You gotta give a complete description. That just broke kids up, they were - they liked it, and it was a novelty to them to think, Yes, I don't know how things taste. Maybe I ought to, if I want to describe it. So that's where we were on different pages. I didn't go around tasting things, but he had his point and his reason for that. Well, that was it. That's how he did it. He [inaudible] told me once how much - don't want to take take up all your tape there, but he later built a house down in Brigantine on the bay - nice. It must have been an old lobster shack and he turned it into a house. I said, Wow, you're down by Atlantic City and the beach.You can just hop over and go to the beach like we did in California. [90 MINUTES] He said, No I can't. I said, Why not? He says, I get too tired. I said, Why do you get tired? He says, I can't stop working when I go to the beach. You go to the beach, you work at the beach. Why can't you stop? He says,"I look and I see different families with their little kiddies and some of them let the little kiddie run wild. No and some of them keep them tethered close to the - wherever the blanket is or whatever they got. And I watch all their styles and so forth. He says, I'm exhausted after I've watched all that stuff. [laughs] I laughed but I understood what he meant. Yeah, he was a good guy. But I know I'm leaving somebody out - it's gonna come to me. I said Hiram Haydn did I, yes?

POOLEY: Well, while you're thinking about that, just as a follow up to Birdwhistell, I think during some of those years he was at least in conversation with a non-Annenberg pair of people including Dell Hymes, who might have been in anthropology or folklore, and Erving Goffman in sociology, and I guess I'm curious whether you ever encountered either of those two, and whether you had any relationship with the sociology department at Penn?

WRIGHT: Well, I met a Goffman a couple of times but we weren't close. And I knew Dell Hymes too, but again we weren't close friends. The connection with Dell was that he was related to Sol Worth. Their children when he got married and all that stuff, but I didn't seek or visit him socially or anything like that. I'm just a lone worker. [laughs] Yeah. The people I got close to that I worked with were - Herb was obviously my main friend and main teacher and main coworker, and his family, we got along. We were in Greece, Italy, we traveled together. It was very good, but I didn't have that close a relationship with people here. Joe [inaudible] out in California, I mentioned him, we spent a lot of time together and we got the same kind of dogs together [laughs] - makes a difference. My wife loved dogs, and I did too. And, again, since I was out there 13 years I began to ... it was a much more social place than my experience at Penn. Partly it's geography: I lived just about a mile from here. We didn't go into town except to see the theater or something now and then, and the scheduled parties or dinners - that was alright. Yeah. 
POOLEY: What kind ...

WRIGHT: Oh, I knew Phil [inaudible] in sociology pretty well; I knew [Samuel] Klausner from Columbia days, but we didn't have a lot of pal-around type things. And my wife and I did things together, and we enjoyed them - that was fine. We both loved the traveling and the sightseeing and that, and we liked people here too - no problem. [95 MINUTES] But work occupied a lot of time, as you're finding out. [laughs] I felt for you when I got your phone call. Oh boy, he's on the trap. He's done! [laughs] You'll get the balance after a while. That's the kind of thing I've learned from Herb Hyman that you don't see in the books and places. Although we mixed home and work we could also at times just separate them. It was very nice.

POOLEY: Well, what kind of leadership style did Gerbner have at Annenberg during those many years when he was the dean?

WRIGHT: I don't know. I don't know how to stylize leadership, [laughs] and a lot of this is just my interpretation of things, but I think that communication, just like sociology, and somewhat like social psych, had to scramble to get academic credibility. So that - and sociology did I should say. For example, there were people who thought the kind of research that Lazarsfeld and others at Columbia did, survey-type stuff, was just looking at trivia. They wanted to look at the big things. But big things grow out of the trivia. [laughs] So, in that sense I think that George had to defend the study of communication - never had to defend like the dance or something but the study of it. Well how do you study it? What's scientific about that? Oh, a lot is scientific. So he had that to contend with, not within the school but with the rest - some, and not all of the university, but some people in the university. Then he had the usual balancing that you do between an artificial notion of the quantitative-qualitative type thing. Then he had also the fact that some people outside didn't like the results of his research saying television causes violence or ... So he had a lot to juggle. I think therefore in the - certainly in the early years of his term he had to keep things defensible, and the enemy was always at the gate about to crash in! [laughs] Therefore, he - you know, he just tried to get things done his own way, and with good reason probably.

POOLEY: You mention ...

WRIGHT: When he finally retired and - as chair - then we had a committee in the university set up to recruit a new dean, and that would settle on Kathleen [Hall] Jamieson - a very fortunate choice: a brilliant lady, a good scholar, and in the public eye in a good way with her research and her books and her work and all that, and also a very caring chair. I think I did tell 
you when I had my open heart surgery she and her family came and sat in the hospital all day waiting to see if I had survived. I never had a dean do that. I was very astonished and very grateful. That's just the kind of person she is. [100 MINUTES] She takes care of her folks. And then we moved to our new dean, and he's quite good too, and also very strong on faculty governance - self governance, which makes for a nice place to work, when you have that. So, I give each of them some good credits for doing what they had to do or liked to do or wanted to do, which is not to say there weren't bumps in the road - as in any organization there are bumps in the road. I think that's true of the whole field - it's life! I wouldn't have stayed that long if I didn't feel that it was a good place to be; the students were good. The program was good. It offers a lot of things in addition to what I do, so nobody's - comes in and is trapped, You have to do this kind of research, and that. At least it wasn't so in the past and I don't think it'll be so in the future either. It's a good place.

POOLEY: In the 1970s, maybe 1980s, you mention that there were some faculty who were more focused on production - television and film production - and other faculty were more research oriented. Right? And that George Gerbner had to deal with the tension that exists everywhere between the people who Identify with qualitative and quantitative research, and I just wonder what it was like in the 1970s with those researchers who were more quantitative, qualitative, and more production-oriented.

WRIGHT: I didn't feel that. No, I didn't. It isn't that we turned our back on production things that's important, that's what's going on. But I don't know, the mechanism for production was getting more and more expensive, you know, as new technology went in, and the faculty who joined us were interested in research and theory and on stuff like that. We kept some vestiges from the past, not - but eventually they sort of slid off. Oh, we prize Sam's work very highly, you see the copies hanging around the walls in the building. So we didn't kick him out or say, Hey, get away. But he had other work that he was doing, I'm sure. Maybe only the language has changed. I don't know, maybe there's still that tension and I didn't know it, but I didn't sense it back then when we were thinking of new appointments. We also have become very much more conscious nowadays of, Is there work for graduates when they get out? That played some part, I guess, in our reduction of the size of the student body, but never was the decision. It was just part of what you do. And I think people who were mainly or strongly production-oriented moved on to other places or other jobs where they could do that. They want to put on like a movie or - Paul [Messaris] plays around a little bit with it. He's especially interested in as new technology comes out, and so that's there and I think that's a good solid groundwork for people who want to do that. [105 MINUTES] But we don't have a course in directing, a course in acting, a course in whatever else of that sort. And at the same we don't have anything music; we don't 
have that. It basically turns into a research-oriented project along the way. And we have the staff that can handle it. Now here's where both the professors and the students have to come eye to eye: we had a very nice student once - I'm not gonna mention any details - very nice student. He was interested in some new popular thing - I forgot what it was called now where you imitate an actor or actress or whomever on the record, and they do it in the bars a lot, and the guy get's up and he thinks he's Bing Crosby - oh that's too old, he thinks maybe he's something else. Anyhow, the stage of research was such that exploratory, qualitative work would have been perfectly reasonable and certainly worth a dissertation project, I thought. But the student thought, He's a qualitative guy. I can't work it him, but l'd like to work with him. But he's a quali - quantitative guy. And he kept trying to design it so that it could be done quantitatively, and I kept saying, No, no, no. [laughs] And I said, Look we're stumped. You're trying to write something that you think is going to please me, and I'm saying 'no don't do that.' [laughs] Don't do that. The problem causes - calls for another, better, different approach. I said, Why don't you go see Carolyn Marvin? And he did, and she took him under her wing, and he got the degree, and he was happy. Why he thought he had to somehow turn it into a survey study or something, I don't know, but that student's misperceptions of the - what it was - I would have been delighted if he had done an [laughs] exploratory study and come up with some typology in the end or whatever it might be. We don't have a lot of that but it happens, and I'm sure it happens at other schools and times.

POOLEY: Yeah, I don't know when Annenberg adopted what it's now since abandoned: this bucket system whereby there were the effects, there were institutional, if I'm not mistaken, and then cultural studies or cultural approaches. Was that a formal division when you arrived, or was it adopted at some point during the intervening years?

WRIGHT: It was invented at some place along the way. It didn't work out, but that's alright. They tried it. You try it. It doesn't work. Get rid of it. Try something else. I'm glad it didn't harden. We were having difficulty with the nature of both sociology and communications is such that there's a ... there are a lot changing, going on within. Things, things become fashionable for a while and then they vanish. How many studies are we going to have six genders now or whatever because that's in the public eye? And anybody who has ever tried to classify any content, whether it was for a business to make up their filing system or whatever, knows how complicated the stuff is or learns how complicated they are or gives up in despair. I'm not sure what, but, so I think it ... it's healthy to see the field is flexible and grows. Not cannibalistic or anything but just [inaudible] along. And I really have not had either the time or the knowledge or the research to know how these digital things are fitting into the scheme. I make that a question for the students when I give my seminar. [110 MINUTES] I say, Look, here's what I said back in the, whatever it was, 1980-something or '90. Now we got this new 
equipment. What difference does it make? Do people do things ? I don't know. Or do they do different things? I don't like the words they use, but behaviors are still solid: people seek information. I called it surveillance - a bad term, but I was, I was stuck. I used it anyhow. But they don't just want information. They want to know how does it affect them, what should they do? There's going to be an earthquake in Southern California, but they can't tell you when, and they can tell you where, and they can't tell you how big. Do you pack up your family and move to Chicago, give up your job? No, you don't do that, you gotta work it out somehow. So, some character commit atrocities in the school or church basement or a celebration like in France. What do you do? Go fly off to the mountains somewhere where you can hide? No, you gotta go on with your life, and communication is part of it, and makes it ... sometimes maybe gives you ideas. But at the least it gives you a sense of what other people are planning or hoping to do. Whether they use a wrist and go tweeter tweeter [inaudible] they're still trying to spread information or opinions or advice, whatever it might be. The speed might be different. It's practically instantaneous nowadays except for a few old fogies, like me, who do not have that, but otherwise, yes, that's different now. You got to take that into account when you do the figuring out the functions of that kind of thing. Its' total - it's different, you know, you don't go into the country store with a line - a rural line that four families are on. No, you don't do that, you do your Dick Tracy act. Yeah, that's it. Is that really one? By golly. I wish my vision was good enough to do that stuff. That'll be part of your generational divide. There's no way I can use that stuff unless they give up trying to make it so tiny, and we don't have, not a wristwatch but a forearm watch. [laughs] You carry it around with you. You laugh, but you'll see it in your day. I won't see it in my day.

POOLEY: Well, let me ask about that class which was the core of your teaching, I think, through your Annenberg days, you know, usually called the Sociology of Communication or Sociology of Mass Communication?

WRIGHT: It's called Media Sociology, and I don't like that term. It's necessary since some students really know about - need to know about how television systems work and so forth and they should. But it's not what I do.

POOLEY: So, how did that class evolve over the three decades that you were teaching it?

WRIGHT: I don't know. When I went from Columbia to UCLA I had begun the course at Columbia. I got to UCLA, there still wasn't anything ... any textbook that approached the problem as I tried to approach it. There were books that did just what you said - paragraph, a chapter on leaflets, a chapter on magazines, a chapter on cigar box radios [laughs] - whatever you had. [115 MINUTES] It was very much oriented ... and then some people got very 
interested in that and that took off, but there was nobody who said, Let's look at this. I take it back. If you went back far enough in the early part, earlier part of the ... and the middle part of the twentieth century you did have some sociologists who were interested in the medium itself. There were often parallels drawn between that stuff - I'm not getting it right ... Some authors thought of it as like equivalent to a transportation system. So you didn't have tracks on a railroad, but nevertheless you were somehow moving information like you'd move goods around, and so they were interested in that. And that's OK. You can refer to that, you know students read it, you can teach it. That's Ok. It just didn't do what I wanted it to do. It got away from me sometimes too, more than I wanted it to. They complement one another, is what I think, probably, and the title might not be as binding or as strict as it sounds: once [inaudible] starts teaching, things spill over into one another. I tend to be a linear person and that gets me in trouble. I think " $B$ " should follow " $A$," and " $C$ " should follow " $B$," and it sometimes is more exciting to stick in a " $Z$ " or an "X." [laughs] I try it sometimes, but I could ... I'll just remind you that in the major research that I have done along with Herb, communication was a hidden thing inside of it. Look, in the Encampment book, what do we come down at the end for the bottom line and find that there were two ingredients in the program that this outfit was running, Ethical Culture Society. One was the didactic one: formally, they'd have guest lecturers come in with that sort of thing, and if a student in the program missed some of that, they changed less than the ones who heard it all. But then side by side with that was the living arrangement. They ate breakfast together. They were on their own at night or they shared a dormitory room or so forth, and so on. If some person - not that they missed one meeting or whatever, may have skipped one breakfast - but if they missed a chunk of it, they changed less. Well, that's communication, because what were they doing in the dormitories at night? They would be arguing the ... like when we were freshmen and you read some book. We used to stay up until two in the morning arguing about that. So that human communication played a very big part in major change in their outlook about life. The problems that they had to face and solve because of the self-governance thing - like who is going to pick up the garbage, who is going to do this, who is going to do that - that all played a part in that too. So, communication was there. It's not that there wasn't also formal or mass communication, but that interpersonal thing was there. And I found that almost - not deliberately, I didn't go out looking for it - but I found that in my early student study, I found it in - well, I can't say I found it in the educational studies that Herb and I did. [120 MINUTES] No, not much.

POOLEY: I would just like to ask ... I was just about to ask about those two books that were published as a part of the educational work. Those didn't have a communication element to them? Did those two books, The Enduring Effects of Education, they did not have a communication angle or element? 
WRIGHT: Only in the sense that - no, I don't want to say [inaudble] ... I might be saying it wrong. But the more formal schooling people had had, made them - seemed to make them more receptive to more information, whether it came through radio or television or newspapers or face-to-face. Maybe it didn't give the same credibility to it. That's another story. But almost, in America at least, by now, almost everybody has and uses access to the mechanisms of mass media. Look, here is a kind of thing you are going to get into when you fiddle around like I did: Email. How could people be so uninformed or careless as to think that something sent by email, when you hit the delete button, vanishes? It doesn't vanish, it obviously ... as people are finding out, who are getting dragged into court about all that. So the human factor is there even, and I spent one class - didn't get very far. I asked them to sort of stylize the social and legal norms that we have about communication. I said, Look, suppose you are talking with a friend, and nobody else is around. They are not wearing a wire. You're just talking to your friends, you consider that private and it's personal. If, however, either by design or by chance, somebody had a recorder nearby and it picked up what you were saying, and then it came out on YouTube, it doesn't mean the same thing as what you said to your friend in private. Oh. I said, Look, we formalize it. Whether it's true or not we say, Tell your lawyer that they can't tell anybody. They could tell somebody - they'd get in trouble - but as even some lawyers are finding out that they get in trouble that way or whatever. So it's all intermixed, and easily spend a lifetime trying to sort it out. I can't. But little pieces of it, students work [inaudible]. Am I crazy? Yeah, I'm crazy. Too late to reform? Yeah, too late to reform. [laughs] I'Il just ... I live with what I've done, and that's ... look, I was never bored. I'm blessed. I got into an occupation, stumbling blindly along the way, and a role called for a variety of things. I had to teach - OK. I have to write and publish - OK. I have to do research, to do the write - unless I want to write fairy tales or fancy things. I got to have data if I want my audience to pay attention, right? I did a little administration dropped on me. If I got ... I just switched from one thing to another, and I didn't even purposefully switched. You are just forced into it. You spend some hours interviewing an old man - you could be doing something different. But you are allowed to do this, and it's even considered in your evaluation and all that. Who could ask for anything more? I work with bright people and bright students. That's a thrill. Just to watch them grow - it's interesting. [125 MINUTES] It sounds corny but it's not. It's closer to what Max Weber called a calling than anything else, I think, and I didn't - maybe others do - but I didn't have it at the beginning. It grew. I think the South American experience just jettisoned me into a another realm. It was marvelous. And I was serious when I told you that I came back to the East Coast because Annenberg had built a school and it was going to be researchoriented - or it was shaping up to be research oriented with George as dean - and that was a big decision. I liked the beaches in California, [laughs] but I can't get to them from here. So I don't know. If you want anything else just ask me and I'll tell you as best I can. 
POOLEY: Well, I think, I think back to something you said in the first session, which was when I asked you about your motivation for writing the book in 1959. You talked about wanting to bring in a sociological perspective into communication research which, in some corners was more psychological. And I don't know if it would be fair to talk about your role at Annenberg over the decades as bringing a sociological voice and approach to the school

WRIGHT: No ...

POOLEY: Not that you were alone in that, because there were ...

WRIGHT: That would not be - that would not be fair. Percy [Tannenbaum] had done it in the beginning, Larry Gross did it, and we may have had, and probably did have, some others that ... no, I didn't mean to do that, I was just ... it just seemed to me that that's the way things were going. People were reducing behavior to being motivated within the individual, and some of it is. Again that's, that's the difference between sociology and some other - some humanistic, as well as some other social sciences. It isn't that everybody behaves the same way - and you never know if you haven't done a survey with random [inaudible] - you never know how common whatever it is you're studying is. You may have picked out an informant who was a little peculiar [laughs] in his or her behavior. If you've done a hundred people and there was only one who behaved the way that one did then you'd know that you did - that one was peculiar, or it might have been just like 51 percent of the rest of the group, so he's not peculiar. But there's now 49 percent that were different from him. That's what you can't get from individual studies, and I've done individual case studies. I know they're interesting - you never know where you stand. Are you outside the envelope or inside the envelope? Yeah, but I did fail to mention something which probably would - should not go in your thing, but you can if you want to. The best thing, one of the best things, from my Columbia undergraduate and graduate experience. I met my wife. And we stayed ... we were married for 51 years.

POOLEY: Can you tell me a little bit about her?

WRIGHT: Yeah, she had a ... perfect some training in home economics and nutrition. She was a nutritionist, and a happy, lovely, friendly person. Put up with this old grump for all those [laughs] years. And she worked ... if she hadn't been working when we got married we would've starved, because I was working on assistantships that didn't pay much back in those days. So that helped put me through school. [130 MINUTES] And she worked out in California; she worked in New York; worked in California. Then when we came back east again we stopped ... by that time, I should be able to put enough bread on the table for us to eat, [laughs] and I could. But that was an unplanned and surprise experience. I just was going through the 
undergraduate ... yeah, yeah, graduate work was ... ah, gee, I thought I'd run out by then. We lived off of her salary and what I pieced together from a couple of assistantships. I got the call from ... the offer from California. Leonard Broom was the chair, he mentioned the salary they were gonna pay an assistant prof. I practically jumped over the Rocky Mountains, [laughs] and went to the West Coast. And that was good. It was a good move: the right place, good colleagues, and good students, but just not quite enough with the same interests I had. They were bright enough, but they had other things that they wanted to do. So Muriel [Cantor] taught me that sometimes a student knows what they want to do, and can do it - and she did, and I was grateful for that. Lovely lady - aneurism got her. Something gets us - very nice ...

POOLEY: You know, as a last question about Annenberg, and I invite you - if there's anything you want to say about Annenberg itself - but you mentioned a student earlier today at Annenberg. I can't remember her name now, but were there students that were as important in some way as Muriel Cantor was at UCLA? In other words, did you have ... are there any students that stand out for you over your time at Annenberg?

WRIGHT: Yes, Josephine Holz was one, Hannah Kliger was another. I don't want to leave people out though. I might hurt their feelings. I don't think I would ... please don't single them out and rank them in some way because they were all ... I ended up with good students. They were all good. They just had different paths, and they amazed me - just continued to amaze me. Hannah, for example, started out with what I thought would be a relatively tight, small project. God, she extended it to be a tremendous contribution to the ethnic studies. She's the one who studied the ... oh, there's a better word for it, but the voluntary associations of immigrant groups. Fascinating. And Jo studied, how did people visualize and make sense out of something that's happening in another city but is relevant to them? But she picked ... it was a period, I've forgotten the exact year now - back in the 1970 sometime, when an outfit in the Midwest was gonna do a neo-Nazi march through a suburb that was mainly populated by survivors of the Holocaust or their relatives. There were big debates about, should that be broadcast, [135 MINUTES] or should it be in the newspapers or not? That was very ... you could change the people ... here's a hostile group that tortured people, or they were connected with. So that was an interesting study. I could go on but just giving you my list of good students, [laughs] which is fine. I'm certainly happy with them. And, again, the trick was to not let it get out of hand if you could. I had another student, Judy [inaudible], who was interested in politics, and she was trying to see where was a good place to put pamphlets or - you know, what the politicians have coming out. And I didn't know where to, how to get her started, but she'd read, by accident, a piece by two older sociologists - Arnold Rose, I think it was, and his wife, I think where they identified places in the neighborhood where there's likely to be conversation and stuff. They had a name for it but I've forgotten what it was. She said, That's what I want to do. 
And I said, OK, but we have to find some place to do this. So we thought and thought and thought and thought, and she decided drugstores was where she was gonna go. People go in for prescriptions. They have pamphlets around; they can pick them up and look through them. Beauty shops, yes ... trapped there for an hour while these women got their hair done and all that sort of stuff. Yeah, OK, and I said, Well, you better throw barber shops in or you're slandering us men. Yeah, so you have to be careful about that. Don't be in there by yourself. Have somebody with you - blah, blah, the usual stuff. Anyhow. So she studied - not the pamphlets - hadn't gotten to that yet. She studied what they talked about, and it was very interesting. It was big enough by the time she found that out. She did a sample of Philadelphia neighborhoods and everything, and it stood as a dissertation by itself. And if she wanted to carry it further that was on her shoulders, but she got her degree. That was, yeah, that was a good study. She got a couple of articles, I think, out of it. I had another student - amy I tying you up here - who was very interested in and upset about homelessness in Philadelphia and how do people find out about it and how is it presented. So she decided to study the stories about homelessness that appeared in the Inquirer, and I think maybe in that time the Bulletin was still in business. I'm not sure. And did a very thorough job of interviewing and studying the stories that they got. Came to the conclusion that there was no consensus whatsoever, and without consensus there was no voluntary group that was formed to sort of defend the homeless, and so forth. The stories ranged from all the way from, Oh, the poor little baby left in the backseat of the car, to, Oh, the drunken bum, [laughs] or whatever. She did a good study made good typologies out of it and all that. That was Bernadette McNulty. [140 MINUTES] She's over at Temple now, I think. Yeah. I don't mean to leave things out I just ... I don't ... I think you shouldn't identify these folks by name. They'll be ... even by dissertation name because it's a small school, and people, they'll say, Oh, he favored this one or that one or ... I didn't favor any of them. I liked them all. There were others but those were things that I thought were both sociological and communication and culture, you know. Though, oh, now we've got all the high-technology, you don't have - by then links were just face-to-face. People talked with one another, talked with their own kind. People from the same country, same town, or whatever it was. Now they can all talk on Twitter or whatever. That may change - change things, I don't know. But I liked Annenberg - I do like Annenberg. They treated me fine, the students were good. Couldn't ask for more - except the beaches. l'd like to bring the beaches back. [laughs] Yeah.

POOLEY: Well, that's a wonderful note on which to end - unless there's something else you'd like to bring up, but l'd like to thank you so much. It was an honor ...

WRIGHT: Oh, you're welcome. 
POOLEY: ... to talk with you these three afternoons, and learn about your career and your trajectory.

WRIGHT: Yeah, well, there were a couple of things. One was I never accept the idea that someone couldn't learn at graduate school because they were stupid or dumb. If they were stupid they wouldn't have gotten this far, therefore there is something else in the way. And that interested me, and interests me, and underwrites some of my studies in education. And, I missed my partner very much, both Herby my work partner, and Ann Marie my home partner. That comes with age. Yeah, I'm glad to see the school at really healthy and standing on its own legs now - it's been a good ride. Thanks for your interviews. I appreciate it.

POOLEY: OK, thank you Charlie.

\section{END OF SESSION THREE}

